\title{
DESENVOLVIMENTO COMO SEGURANÇA, ASSALTO À POBREZA E AJUSTAMENTO ESTRUTURAL: O BANCO MUNDIAL DURANTE OS ANOS MCNAMARA \\ (1968-1981)
}

João Márcio Mendes Pereira

Universidade Federal Rural do Rio de Janeiro

\begin{abstract}
Resumo
$\mathrm{O}$ artigo analisa a atuação do Banco Mundial durante a gestão de Robert McNamara, situando-a nos marcos da guerra fria e da condução da política externa norte-americana, cada vez mais sujeita à ingerência do Congresso. Discute as razões e os meios pelos quais o Banco Mundial conduziu, a partir de 1968, a consigna do "assalto à pobreza" e faz um balanço dessa experiência. Por fim, aborda o lançamento dos empréstimos de ajustamento estrutural em 1980, à luz das mudanças radicais na economia política internacional ocorridas entre 1979 e 1981.
\end{abstract}

Pallavras-chave

Banco Mundial $\bullet$ guerra fria $\bullet$ pobreza.

\section{Contato:}

Rua José Higino, 215, apto. 601

20520-201 - Tijuca - Rio de Janeiro - RJ

E-mail: joao_marcio1917@yahoo.com.br

* O presente artigo sintetiza aspectos discutidos extensamente em PEREIRA, João Márcio Mendes. O Banco Mundial como ator político, intelectual e financeiro (1944-2008). Rio de Janeiro: Civilização Brasileira, 2010. 


\title{
DEVELOPMENT AS SECURITY, THE ASSAULT ON POVERTY AND STRUCTURAL ADJUSTMENT: THE WORLD BANK DURING THE MCNAMARA YEARS (1968-1981)
}

\author{
João Márcio Mendes Pereira \\ Universidade Federal Rural do Rio de Janeiro
}

\begin{abstract}
The article analyzes the World Bank's action during Robert McNamara's presidency, situating it in the context of the Cold War and the conduct of American foreign policy, which was increasingly subordinated to interference by the United States Congress. It discusses the reasons and means through which the World Bank conducted, since 1968, its "assault on poverty" and makes a general interpretation of this experience. Finally, it deals with the launching of structural adjustment loans in 1980 under the radical changes in the international political economy which occurred between 1979 and 1981.
\end{abstract}

\section{Keywords}

World Bank • Cold War • poverty.

\section{Contato:}

Rua José Higino, 215 - apt. 601

20520-201 - Tijuca - Rio de Janeiro - RJ

E-mail: joao_marcio1917@yahoo.com.br 
A segurança dos Estados Unidos deve continuar a apoiar-se numa observância da política de segurança coletiva e não recuar (...) para a fútil ilusão do isolacionismo (...). Permanece o fato incontestável de nossa segurança estar diretamente ligada à segurança desse novo mundo em desenvolvimento (...). Numa sociedade que está se modernizando, segurança significa desenvolvimento (...). Sem desenvolvimento interno, pelo menos em grau mínimo, ordem e estabilidade são impossíveis.

Robert McNamara. A essência da segurança, 1968.

Robert McNamara, ex-aluno da Harvard Business School e ex-presidente da Ford Motor Company, ocupava o cargo de secretário de Defesa dos EUA desde 1961 quando foi guindado pela Casa Branca para a presidência do Banco Mundial. ${ }^{1} \mathrm{O}$ primeiro presidente da instituição não oriundo das hostes de Wall Street deu início à sua gestão em abril de 1968, conduzindo a entidade, que até então

1 O Banco Mundial integra o chamado Grupo Banco Mundial (GBM) que é constituído por sete organizações com diferentes mandatos, gravitação política, estruturas administrativas e instâncias de decisão. São elas: Banco Internacional para a Reconstrução e o Desenvolvimento (Bird), criado junto com o Fundo Monetário Internacional (FMI) na conferência de Bretton Woods em 1944; Associação Internacional de Desenvolvimento (AID), criada em 1960; Corporação Financeira Internacional (CFI), de 1956; Centro Internacional para Conciliação de Divergências em Investimentos (CICDI), de 1966; Agência Multilateral de Garantias de Investimentos (AMGI), de 1988; Instituto de Desenvolvimento Econômico (IDE), de 1955, renomeado de Instituto do Banco Mundial (IBM) em 2000; e Painel de Inspeção, criado em 1993. O Banco Mundial é formado apenas pelo Bird e pela AID, mas mantém estreita articulação com o conjunto do GBM, à exceção, em parte, do Painel de Inspeção. O Bird concede empréstimos a países de renda média e de baixa renda solventes, captando recursos em mercados de capital e emprestando a seus clientes em condições próximas às do mercado financeiro internacional (hard loans). O lastro das suas operações denomina-se capital geral e é aportado pelos estados-membros, em proporções desiguais, e só pode ser aumentado após negociações entre eles. Já a AID efetua empréstimo de longo prazo e com baixas taxas de juros (soft loans) a países pobres com pouca ou nenhuma capacidade de tomar emprestado nas condições de mercado. AAID tem três fontes de financiamento: contribuições do Bird, pagamento com juros dos empréstimos que realiza e, a mais importante, contribuições voluntárias negociadas entre países doadores a cada três anos. Enquanto o Bird dá lucro e se baseia financeiramente no mercado, a AID depende das contribuições voluntárias de alguns estados doadores para sobreviver. A fatia de cada doador enseja negociações intensas com os demais. O poder de voto no Banco Mundial - assim como no FMI - é desigual e proporcional ao capital aportado por cada Estado-membro, quantia que é negociada politicamente entre os estados. Por um acordo informal vigente desde 1944, o presidente do Banco Mundial é sempre um cidadão norte-americano indicado pelos Estados Unidos. Uma análise detalhada das funções de cada organização e da divisão de trabalho no interior do GBM, bem como da hierarquia entre os acionistas do Banco, pode ser encontrada em PEREIRA, João Márcio Mendes. $O$ Banco Mundial como ator político, intelectual e financeiro, op. cit., cap. 1. 
havia sido "quase um apêndice do Tesouro dos EUA", ${ }^{2}$ pela trilha da diplomacia do desenvolvimento.

O símbolo mais forte dessa atuação seria a conexão entre segurança e desenvolvimento. ${ }^{3}$ De acordo com essa abordagem, a segurança dos EUA dependia não apenas da sua supremacia militar, mas também da preservação da ordem política nos países da periferia. A chave para isso era a promoção do "desenvolvimento", i. e., crescimento econômico, melhoria dos indicadores sociais básicos e redução da desigualdade socioeconômica. A rigor, tal abordagem não era nova e orientava programas aplicados com mais ou menos vigor na América Latina desde o começo da guerra fria, como o Desenvolvimento de Comunidade nos anos 1950 e a Aliança para o Progresso nos anos $1960 .^{4}$

É interessante notar que a relação direta estabelecida entre pobreza e instabilidade era válida, para McNamara, para qualquer sociedade marcada por desigualdades profundas, inclusive os Estados Unidos. Seu livro relata, por exemplo, que, em 1966, um terço dos alistados para o serviço militar haviam sido rejeitados por "problemas de ordem física e, sobretudo, educacional", e que, em algumas áreas, o "índice de rejeição de negros" havia passado de $80 \%{ }^{5}$ A sua conclusão geral era taxativa: "a pobreza nos EUA é um câncer social (...). Em seis americanos, um se encontra colhido em suas malhas (...). Esses americanos - 32 milhões vivem em todos os estados". ${ }^{6}$ Em resposta à degradação dos indicadores sociais e à escalada das lutas por direitos civis, emprego e melhores condições de vida em mais de cem cidades norte-americanas, o governo Johnson lançou uma série de iniciativas sociais, entre as quais o programa Grande Sociedade, o Guerra à Pobreza e o apoio federal aos ensinos secundário e superior. ${ }^{7}$

A retomada dessa abordagem no final dos anos sessenta devia muito ao reconhecimento do fracasso da via predominantemente militar seguida pelos EUA no Vietnã. ${ }^{8}$ À medida que se estilhaçava o consenso bipartidário nos EUA em

2 AYRES, Robert. Banking on the poor: the World Bank and world poverty. $1^{\mathrm{a}}$ edição. Londres: MIT Press, 1983, p. 7.

3 McNAMARA, Robert. A essência da segurança. $1^{\text {a }}$ edição. São Paulo: Ibrasa, 1968.

4 Cf. LANCASTER, Carol. Foreign aid: diplomacy, development, domestic politics. Chicago/ Londres: The University of Chicago Press, 2007; LATHAM, Michael. Modernization as ideology: American social science and "nation building" in the Kennedy era. Chapel Hill/Londres: The University of Carolina Press, 2000; ESCOBAR, Arturo. La invención del Tercer Mundo: construcción y deconstrucción del desarrollo. Bogotá: Editorial Norma, 1996.

5 McNAMARA, Robert. A essência da segurança, op. cit., p. 149.

6 Idem, p. 150-151.

7 AZEVEDO, Cecília. Guerra à pobreza: EUA, 1964. Revista de História (USP). São Paulo, vol. $153, \mathrm{n}^{\mathrm{0}} 2,2005$, p. 305-323.

8 KAPUR, Devesh et al. The World Bank: its first half century. History. $1^{\text {a }}$ edição. Washington: 
relação à política externa, a estratégia da contenção do comunismo empregada desde 1947 foi progressivamente abandonada no final dos anos sessenta e início da década seguinte. ${ }^{9}$ No âmbito da assistência externa ao desenvolvimento, a resposta do governo a essa situação consistiu no aumento da assistência multilateral frente à ajuda bilateral. Para Washington, o Banco Mundial e os demais bancos multilaterais de desenvolvimento (BMDs) podiam alavancar fundos para os países da periferia relevantes do ponto de vista geopolítico para os EUA sem atrair críticas diretas à política externa e sem o ônus econômico dos programas bilaterais. Em outras palavras, a consolidação do Banco Mundial como uma "agência de desenvolvimento" durante a gestão McNamara foi um movimento firmemente apoiado por Washington.

Em seu primeiro discurso, McNamara fez um balanço socioeconômico dos anos sessenta e concluiu que o resultado era desapontador, porque a desigualdade de renda entre as nações havia aumentado e a maior parte da população do planeta permanecia vivendo em condições de pobreza extrema, apesar da elevação das taxas de crescimento econômico em grande parte dos países da periferia. ${ }^{10}$ Tudo isso implicava o reconhecimento de que o modelo econômico dominante havia falhado e que os benefícios do crescimento não haviam escorrido para baixo, como pregava a doutrina do "efeito derrame". ${ }^{11}$ Assim, para McNamara, era preciso distinguir teoricamente crescimento econômico de redução da pobreza e abordá-los de maneira separada. Essa ideia se tornou a base da consigna da redução "direta" da pobreza. Por outro lado, McNamara se recusou a admitir que a redução da pobreza pudesse vir a expensas da promoção do crescimento, como afirmava a imensa maioria dos economistas do Banco naquela época, e sempre insistiu na centralidade do crescimento econômico. ${ }^{12}$

Brookings Institution Press, vol. 1, 1997, p. 220.

9 GWIN, Catherine. U.S. relations with the World Bank, 1945-1992. In: KAPUR, Devesh et al (eds.). The World Bank: its first half century - Perspectives. 1 ${ }^{\text {a }}$ edição. Washington: Brookings Institution Press, vol. 2, 1997, p. 210-211.

${ }^{10}$ McNAMARA, Robert. A imposição do desenvolvimento. In: McNAMARA, Robert. Cem países, dois bilhões de seres: a dimensão do desenvolvimento. $1^{\text {a }}$ edição. Rio de Janeiro: Fundação Getúlio Vargas, 1974, p. 4-5.

${ }^{11}$ Uma das coordenadas intelectuais que guiavam o Banco era a de que a distribuição de renda se concentrava nos estágios iniciais do ciclo econômico e se desconcentrava nos estágios finais, de tal maneira que, após uma fase ascendente de crescimento econômico, operar-se-ia o "efeito derrame" (trickle-down), i. e., o gotejamento gradual de renda para os estratos mais baixos da estrutura social. Quanto tempo esse processo duraria e qual a intensidade e o alcance do derrame acabaram se tornando questões secundárias naquele período frente à própria crença no derrame.

${ }^{12}$ KAPUR, Devesh et al. The World Bank: its first half century. History, op. cit., p. 217. 
A consigna do "assalto à pobreza" figurou no centro do discurso da nova gestão. Em nome dela, McNamara anunciou metas ambiciosas para o quinquênio 1968-73: nada menos do que a duplicação da carteira de empréstimos. Além disso, anunciou a ampliação dos empréstimos para o setor agropecuário e para a área "social", como educação, fornecimento de água potável, saneamento básico, nutrição, saúde primária, habitação urbana e planejamento familiar.

Além de câmbios na alocação setorial, a nova gestão modificou a destinação geográfica dos empréstimos. Embora os desembolsos para a Ásia fossem intensificados - em particular, para dar conta do retorno da Indonésia como cliente do Banco após o golpe militar, apoiado pelos EUA, que levou Suharto ao poder em 1968 - McNamara indicou que as operações na África e na América Latina deveriam duplicar e triplicar, respectivamente. ${ }^{13}$

Para aumentar o caixa do Bird, McNamara expandiu a venda de títulos em praças financeiras da Europa. ${ }^{14}$ A partir de então, a capacidade do Banco de emprestar passou a estar baseada cada vez mais na sua capacidade de tomar empréstimos, necessitando cada vez menos de novos aportes de capital dos cinco maiores acionistas. ${ }^{15}$ Por sua vez, a reposição de fundos da AID, para o período 1969-71, aumentou 40,7\% em relação ao triênio $1965-68 .{ }^{16}$ Por tudo isso o Banco estava em condições extraordinárias para alavancar empréstimos.

McNamara estabeleceu metas anuais de empréstimos para cada país e definiu que a eficiência profissional de cada funcionário seria avaliada segundo o volume de recursos envolvido nos projetos sob sua responsabilidade. O que importava não era propriamente a qualidade técnica, muito menos a utilidade socioeconômica e o impacto dos projetos nos países receptores, mas sim que o objetivo de emprestar ocorresse da maneira mais rápida possível, de acordo com a linha política da instituição. O imperativo de "mover o dinheiro" a qualquer custo tornou-se, desse modo, um dos traços mais marcantes da cultura organizativa do Banco.

O desembolso do crédito dependia da criação de projetos financiáveis. Para isso, o Banco enviava seus funcionários desde Washington para que oferecessem projetos aos governos dos estados clientes. ${ }^{17}$ Por outro lado, do ponto de vista governamental, o acesso ao dinheiro do Banco Mundial funcionava como um

${ }^{13}$ McNAMARA, Robert. A imposição do desenvolvimento, op. cit., p. 8-9.

${ }^{14}$ BANCO MUNDIAL. Annual report. Washington: The World Bank, 1969, p. 28-29.

${ }^{15}$ GOLDMAN, Michael. Imperial nature: the World Bank and struggles for social justice in the age of globalization. $1^{\text {a }}$ edição. New Haven/Londres: Yale University Press, 2005, p. 63-64.

${ }^{16}$ KAPUR, Devesh et al. The World Bank: its first half century. History, op. cit., p. 1.137.

${ }^{17}$ GEORGE, Susan e SABELLI, Fabrizio. La religión del crédito: el Banco Mundial y su imperio secular. $1^{\text {a }}$ edição. Barcelona: Intermón, $2^{\text {a }}$ edición, 1996, p. 57-58. 
catalisador de empréstimos e créditos externos. Assim, para os governos, fechar acordos com o Banco propiciava ou facilitava o acesso a outras fontes de recursos, privadas e públicas, fomentando ainda mais a espiral de endividamento externo.

Seguindo a mesma lógica expansiva e de diversificação, o Banco Mundial passou a autorizar, a partir de 1968, empréstimos para empresas públicas e bancos nacionais e regionais de desenvolvimento. ${ }^{18}$ Até então, o Banco havia se negado a efetuar esse tipo de operação, alegando que aquelas instituições eram ineficientes. Esse giro, embora suscitasse resistências internas, respondia a uma série de fatores. Em primeiro lugar, ao crescimento real do setor público nos países da periferia, alguns dos quais com grau considerável de industrialização e todos, sem exceção, clientes do Banco. Em segundo lugar, à capacidade do setor público de absorver e contrair empréstimos em grande escala, bastante superior ao que seria possível fazê-lo por meio de empresas privadas singulares. Em terceiro lugar, à própria dinâmica política internacional, que impunha certa tolerância das grandes potências, em especial dos EUA, em relação a alguns governos que implementavam políticas econômicas desenvolvimentistas, desde que o seu alinhamento político mais amplo fosse inequívoco e não ameaçasse ativos e investimentos estrangeiros, ou com os quais fosse indispensável manter ou ampliar relações políticas, devido à sua posição estratégica no tabuleiro geopolítico da guerra fria. Em quarto lugar, à possibilidade de utilizar recursos do Banco para ampliar o financiamento a empresas privadas utilizando os bancos nacionais e regionais de desenvolvimento como intermediários. ${ }^{19}$ Tal giro, contudo, jamais implicou qualquer apoio do Banco a estratégias soberanas de desenvolvimento nacional, nem pretendeu remediar o caráter dependente das economias periféricas. ${ }^{20}$

Como parte desse movimento expansivo e da crescente ênfase no setor rural, o Banco se articulou às fundações Ford e Rockefeller em 1969 para criar uma rede internacional de centros de pesquisa agrícola que impulsionasse a difusão dos pacotes tecnológicos da Revolução Verde pelo mundo. ${ }^{21}$ A iniciativa culminou na criação do Grupo Consultivo para a Pesquisa Agrícola Internacional (CGIAR) em

${ }^{18}$ MASON, Edward e ASHER, Robert. The World Bank since Bretton Woods. $1^{\text {a }}$ edição. Washington: The Brookings Institution, 1973, p. 744.

${ }^{19}$ PAYER, Cheryl. The World Bank: a critical analysis. $1^{\text {a }}$ edição. Nova Iorque: Monthly Review Press, 1982, p. 128.

${ }^{20}$ LICHTENSZTEJN, Samuel e BAER, Mônica. Fundo Monetário Internacional e Banco Mundial: estratégias e políticas do poder financeiro. $1^{\text {a }}$ edição. São Paulo: Brasiliense, 1987, p. 178-180.

${ }^{21}$ MASON, Edward e ASHER, Robert. The World Bank since Bretton Woods, op. cit., p. 574; KAPUR, Devesh et al. The World Bank: its first half century. History, op. cit., p. 399. 
maio de 1971. Os quatro centros internacionais de pesquisa agrícola criados pelas duas fundações durante os anos sessenta - o Instituto Internacional de Investigação sobre o Arroz (IRRI) nas Filipinas, o Centro Internacional de Melhoramento de Milho e Trigo (CIMMYT) no México, o Instituto Internacional de Agricultura Tropical (IITA) na Nigéria e o Centro Latino-Americano para Agricultura Tropical (Ciat) na Colômbia - formaram os pilares iniciais do CGIAR que, rapidamente, se expandiu com a criação de novos centros. O Banco encabeçou a iniciativa, desempenhando um papel de liderança política e intelectual desde então. O novo sistema ganhou forte apoio público e privado e contou com inúmeros doadores. Dois lideraram a lista: a Usaid, responsável por um quarto do total dos fundos, e o Banco Mundial, responsável por $10 \%$ dos recursos. ${ }^{22}$

A ênfase do Banco Mundial na agricultura alimentava-se também da tese, convertida em doutrina do desenvolvimento agrícola, segundo a qual os agricultores "tradicionais" seriam receptivos a incentivos econômicos e predispostos à otimização da produção segundo parâmetros capitalistas. Ou seja, dentro das condições disponíveis, eles já seriam produtores eficientes. O trabalho de Theodor Schultz - o mesmo que, poucos anos depois, seria um dos "pais" da teoria do capital humano - foi um marco dessa nova visão, que deu racionalidade econômica à elaboração de projetos voltados à modernização técnica de frações do campesinato, transformando-os em clientes do desenvolvimento. ${ }^{23}$

As pesquisas sobre a primeira geração das variedades de trigo e arroz de alto grau de resposta produzidas pelo CIMMYT e pelo IRRI saíram no início dos setenta e serviram para estimular a difusão do plantio. Os resultados excepcionais de algumas colheitas reforçaram a ideia de que investir no CGIAR era um negócio altamente lucrativo. Articulado com seus parceiros bilaterais, o Banco estimulou os estados clientes a criarem centros de investigação agropecuária em toda a periferia. A malha de instituições vinculadas ao CGIAR rapidamente se ampliou e se ramificou pelos âmbitos da ciência, das agências de assistência bilateral e multilateral e das corporações agroindustriais, dando origem a um complexo de poder baseado em um tipo específico de produção de conhecimento. Milhares de técnicos e cientistas passaram a ser educados pelo sistema CGIAR e muitos deles depois ocuparam posições de destaque como ministros de Estado

${ }^{22}$ KAPUR, Devesh et al. The World Bank: its first half century. History, op. cit., p. 401.

${ }^{23}$ SCHULTZ, Theodor. A transformação da agricultura tradicional. Rio de Janeiro: Zahar, 1965; OLIVER, Robert W. George Woods and the World Bank. Boulder/Londres: Lynne Rienner, 1995, p. 165; ESCOBAR, Arturo. La invención del Tercer Mundo: construcción y deconstrucción del desarrollo, op. cit., cap. 4 e 5. 
e membros de diretorias de centros de pesquisa e empresa multinacionais. $\mathrm{O}$ intercâmbio promovido pelo CGIAR começou a carrear dólares para os institutos nacionais de pesquisa por meio de parcerias com universidades norte-americanas, impulsionando a norte-americanização dos sistemas agroalimentares nacionais, de leis de propriedade e leis de comércio e investimento nos países clientes. Formada pela tríade ciência-empresas-estados, essa rede ajudou a expandir os ramos industriais ligados à Revolução Verde (energia, fertilizantes, pesticidas químicos, sementes sintéticas, maquinário agrícola etc.). ${ }^{24}$

A ênfase no setor rural, por sua vez, foi usada pelo Banco para diversificar a sua carteira de empréstimos em diversas direções: crédito agrícola (repassado aos produtores por intermédio de bancos nacionais de desenvolvimento), construção de grandes barragens para eletricidade e irrigação, mineração, transporte, empresas de maquinário agrícola, desenvolvimento urbano e educação e saúde básicas no interior. De longe, irrigação, drenagem e administração de água foi o principal subsetor dentro da agropecuária financiado pelo Banco nos anos cinquenta e sessenta, e continuou assim nos setenta, principalmente na Ásia, no Oriente Médio e na América Latina. A maior parte do aumento da produção agrícola dos países da periferia vinha de áreas irrigadas novas ou reabilitadas. Os insumos da Revolução Verde, sobretudo fertilizantes químicos, requeriam uma hidrologia altamente favorável e o Banco cumpriu um papel de pivô nesse processo. $\mathrm{Na}$ maioria dos países, porém, a irrigação apresentou sérios problemas de equidade. Os grandes proprietários frequentemente obtiveram acesso preferencial à água e tenderam a se beneficiar desproporcionalmente dos canos públicos. Em matéria de eletrificação rural, o financiamento veio junto com a exigência de recuperação de custos. Nos empréstimos para transporte, o Banco encorajou os estados a priorizarem o rodoviário e a delegarem maior capacidade de financiamento e responsabilidade às esferas subnacionais de governo. ${ }^{25}$ Quanto ao crédito agrícola, a maior parte foi canalizada para grandes produtores comerciais. ${ }^{26}$

A tabela 1 compara a carteira de empréstimos do Banco durante a gestão McNamara e a anterior, desagregando os dados por grupos de países. A tabela 2, na sequência, compara a fatia de cada setor na carteira do Banco no mesmo período.

\footnotetext{
${ }^{24}$ GOLDMAN, Michael. Imperial nature: the World Bank and struggles for social justice in the age of globalization, op. cit., p. 86-87.

${ }^{25}$ KAPUR, Devesh et al. The World Bank: its first half century. History, op. cit., p. 404-407.

${ }^{26}$ BANCO MUNDIAL. Reforma de la tenencia de la tierra. Washington: The World Bank, 1975, p. 59.
} 
Tabela 1. Volume de empréstimos do Banco Mundial entre 1961-82 (milhões de dólares)

\begin{tabular}{|c|c|c|c|c|c|}
\hline & 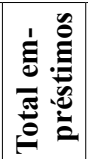 & $\begin{array}{l}\overline{\mathfrak{T}} \\
\stackrel{+}{\dot{a}}\end{array}$ & $\begin{array}{l}\vec{\infty} \\
\stackrel{n}{n}\end{array}$ & $\begin{array}{l}\text { 寺 } \\
\text { 它 }\end{array}$ & $\begin{array}{l}\hat{g} \\
\dot{m}\end{array}$ \\
\hline & 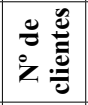 & $\Xi$ & $=$ & $n$ & $\stackrel{\infty}{+}$ \\
\hline 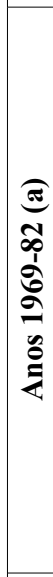 & 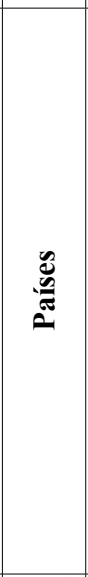 & & 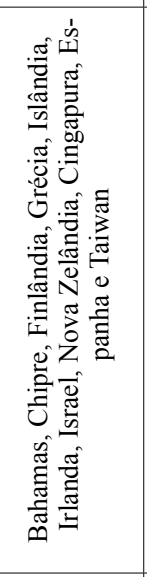 & 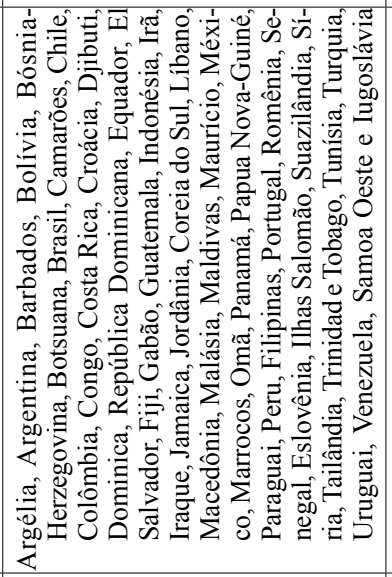 & 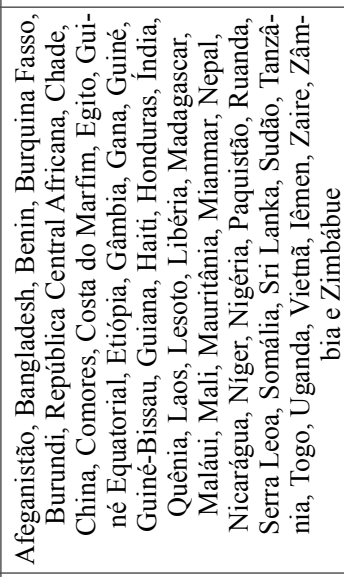 \\
\hline & 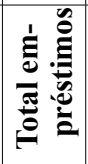 & 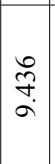 & 总 & $\begin{array}{l}\hat{\delta} \\
\text { f. } \\
\dot{\gamma}\end{array}$ & ò \\
\hline & 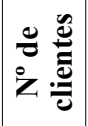 & $\hat{\alpha}$ & $\stackrel{\circ}{-}$ & $\stackrel{m}{f}$ & m \\
\hline $\begin{array}{l}\frac{0}{1} \\
\frac{1}{0} \\
\frac{0}{2} \\
\frac{6}{2}\end{array}$ & 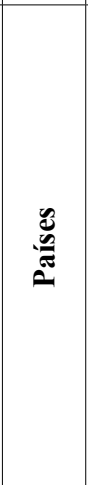 & & 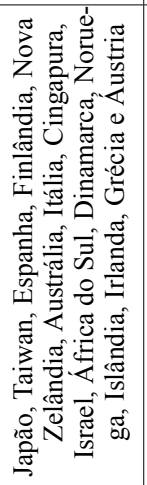 & 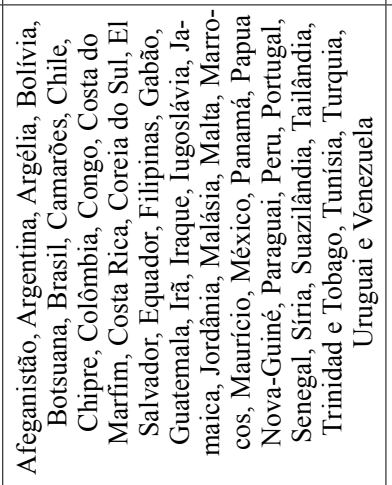 & 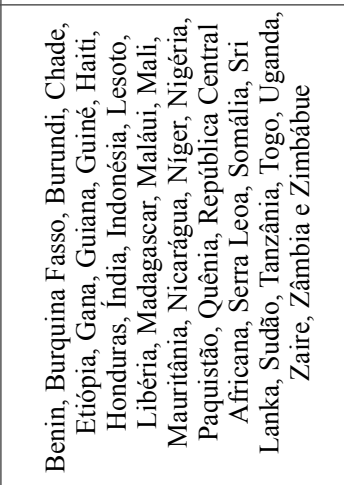 \\
\hline & 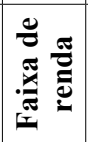 & है & 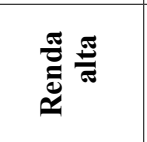 & 丞 & قِّ \\
\hline
\end{tabular}


O período McNamara inclui os compromissos de $1^{\circ}$ de julho de 1968 a 30 de junho de 1982, com base no pressuposto de que os compromissos de empréstimo feitos durante o ano fiscal de 1982 refletem decisões e preparação realizadas sob McNamara.

Tabela 2. Empréstimos do Banco Mundial por setor - 1961-82 (percentual)

\begin{tabular}{|c|c|c|c|}
\hline Setores & $\mathbf{1 9 6 1 - 6 9}$ & $\mathbf{1 9 6 9 - 7 3}$ (a) & $\mathbf{1 9 7 4 - 8 2}$ \\
\hline Transporte, energia e telecomunicações (b) & 64,1 & 47 & 35 \\
\hline Agricultura & 12,2 & 20 & 29 \\
\hline Educação & 2,5 & 5 & 4 \\
\hline População, saúde e nutrição & 0 & 1 & 1 \\
\hline Desenvolvimento urbano & 0 & menos de 0,5 & 2 \\
\hline Água e saneamento & 1,7 & 5 & 5 \\
\hline Outros (c) & 19,5 & 21,5 & 24 \\
\hline
\end{tabular}

Fonte: Kapur et al. The World Bank: its first half century. History, op. cit., p. 141 e 235.

(a) O período McNamara inclui os compromissos de $1^{\circ}$ de julho de 1968 a 30 de junho de 1982, com base no pressuposto de que os compromissos de empréstimo feitos durante o ano fiscal de 1982 refletem decisões e preparação realizadas sob McNamara.

(b) Inclui mineração.

(c) Inclui as seguintes rubricas: créditos para importação industrial; assistência técnica e créditos para importação comercial; finanças; indústria e ajustamento estrutural.

Apesar da diversificação setorial e geográfica relativa e do aumento notável da atividade financeira do Banco no quinquênio 1968-1973, quase três quartos dos empréstimos para projetos foram para o mesmo de sempre: energia, transportes, telecomunicações e créditos para importação e políticas macroeconômicas. Por outro lado, avaliações feitas na época pelo próprio Banco identificaram que os projetos para agricultura e educação não chegavam aos segmentos considerados mais pobres da população. ${ }^{27}$ Por isso, para grande parte do staff, havia um con-

\footnotetext{
${ }^{27}$ KAPUR, Devesh et al. The World Bank: its first half century. History, op. cit., p. 246.
} 
traste enorme entre a retórica pro-poor de McNamara e o cotidiano dos negócios do Banco. $^{28}$

\section{A política norte-americana para o Banco Mundial durante 1968-73}

A expansão da atividade financeira durante o primeiro quinquênio da gestão McNamara teve de enfrentar a queda do apoio público nos EUA à assistência ao desenvolvimento, provocado tanto pela deterioração dos indicadores macroeconômicos domésticos, quanto pela destruição do consenso bipartidário em matéria de política externa. Por um lado, as relações com o Tesouro norte-americano sofreram atritos devido a diversas questões, entre as quais os pedidos crescentes de fundos, em particular à AID, e os efeitos da captação de dólares pelo Bird no mercado financeiro norte-americano sobre o balanço de pagamentos. Por outro lado, o Congresso se tornou cada vez mais vigilante e crítico à atuação bilateral e multilateral do país. Este ponto merece maior consideração.

Antes do início dos anos setenta, a rigor, o Congresso - que dera forte apoio à criação do Banco Mundial - havia se limitado, na maior parte do tempo, à aprovação de requerimentos administrativos para o diretor norte-americano no Banco e à provisão de fundos para ele. Ou seja, um papel passivo. ${ }^{29}$ Porém, com o fim do consenso bipartidário e num período em que a economia enfrentava problemas sérios, a atenção congressual à ajuda bilateral e à atuação dos BMDs aumentou, à medida que os pedidos de fundos cresciam aceleradamente. No caso do Banco Mundial, a expansão do seu programa de empréstimos sob McNamara passou a atrair, aos poucos, a atenção de parlamentares e grupos de interesse diversos, pluralizando a relação do Banco com os poderes norte-americanos. Assim, além do Tesouro e do Departamento de Estado, cada vez mais o Banco teve de responder ao Congresso. Muitos parlamentares passaram a se opor à escalada bélica dos EUA no Vietnã e às tentativas dos governos Johnson e Nixon de usar a assistência bilateral e multilateral ao desenvolvimento para apoiar a ofensiva militar. A presença de McNamara à frente do Banco Mundial associava a instituição diretamente à guerra e à política externa norte-americana.

Para driblar o aumento da ingerência do Congresso sobre o programa de ajuda bilateral, o Executivo passou a dar mais peso, em termos relativos, à assistência multilateral, modalidade mais difícil de ser supervisionada. ${ }^{30}$ Tanto assim que,

\footnotetext{
${ }^{28}$ MASON, Edward e ASHER, Robert. The World Bank since Bretton Woods, op. cit., p. 732; KAPUR, Devesh et al. The World Bank: its first half century. History, op. cit., p. 233.

${ }^{29}$ GWIN, Catherine. U.S. relations with the World Bank, 1945-1992, op. cit., p. 211-212.

${ }^{30}$ BURBACH, Roger e FLYNN, Barbara. Agroindústria nas Américas. $1^{\text {a }}$ edição. Rio de Janeiro:
} 
em 1972, um documento da Câmara afirmou que o Congresso não tinha controle sobre quando, onde e como os recursos solicitados eram gastos pelos BMDs, uma vez que eles não justificavam seus pedidos por projetos específicos. Nos anos seguintes, o Legislativo repetiu essa reclamação insistentemente. Diversos pronunciamentos e expedientes destacaram a inadequação da consulta do Executivo ao Congresso, a urgência de mais informações sobre o Banco Mundial e a necessidade de procedimentos de avaliação e auditoria independentes e transparentes. ${ }^{31}$

Com a deterioração da disciplina e da liderança partidárias no Congresso durante o governo Nixon, tornou-se cada vez mais difícil para o Executivo manobrar pedidos de verbas para ajuda externa dentro do Legislativo. Nada menos do que cinco comitês congressuais vieram a ter jurisdição sobre a política dos EUA para o Banco Mundial, o que possibilitou a grupos com agendas políticas específicas e parlamentares estrategicamente situados ganharem peso desproporcional e influenciarem o processo decisório. ${ }^{32} \mathrm{Na}$ ausência de uma base parlamentar forte e coesa que pudesse ser mobilizada para obstaculizar a proliferação de emendas particularistas, o Executivo assistiu não apenas ao aumento do controle do Congresso sobre a ajuda bilateral, como também ao surgimento gradual de um extenso corpo legislativo sobre a relação dos EUA com o Banco. ${ }^{33}$ Esse processo, que teve início no primeiro quinquênio da gestão McNamara, avançou ininterruptamente dali em diante.

Em 1972, saiu uma das primeiras ações legislativas específicas sobre o Banco. A chamada Emenda Gonzalez determinou que os EUA se opusessem a empréstimos do Banco para países que tivessem confiscado investimentos privados norteamericanos sem a compensação devida. A lei, na verdade, estendeu para todos os BMDs uma restrição já imposta aos programas bilaterais e à representação do país no BID pela Emenda Hickenlooper, editada em 1962. ${ }^{34}$

Um ano depois, durante as negociações para a quarta reposição de fundos da AID em 1973, os EUA se posicionaram, pela primeira vez, como o principal doador favorável à limitação do aumento nas contribuições. Para que isso não ocorresse, o Banco e os demais doadores foram obrigados a aceitar inúmeras concessões. ${ }^{35}$ Uma delas era a de que o Banco reduzisse os empréstimos ao Peru, como sanção à nacionalização da International Petroleum Company, em 1969,

Zahar, 1982, p. 72-73.

${ }^{31}$ GWIN, Catherine. U.S. relations with the World Bank, 1945-1992, op. cit., p. 220-221.

${ }^{32}$ Ibid, p. 212.

${ }^{33}$ Ibid, p. 220.

${ }^{34}$ Ibid, p. 220.

${ }^{35}$ Ibid, p. 215. 
realizada pelo governo Velasco Alvarado. Outra exigência norte-americana era a de que a sua cota na AID fosse reduzida e as reposições ocorressem a cada quatro anos, em vez de três. Essa mudança no calendário permitiu aos EUA manterem o seu pagamento anual em dólares correntes no mesmo patamar da terceira reposição, enquanto os demais doadores tiveram que reajustar as suas contribuições.

Em outras palavras, durante o primeiro quinquênio da gestão McNamara, a expansão da atividade financeira do Banco Mundial se deu num quadro político de queda do apoio à ajuda ao desenvolvimento nos EUA, provocado pelo fim do consenso bipartidário sobre a política externa e pelo agravamento das condições macroeconômicas do país (estagflação, déficits contínuos no balanço de pagamentos e enfraquecimento internacional do dólar). Resultado: dificuldades crescentes para se obter recursos do seu principal acionista. $\mathrm{O}$ ativismo cada vez maior do Congresso em matéria de política externa criou oportunidades e meios para críticas à participação dos EUA nos BMDs e à atuação dessas instituições. A falta de transparência do Banco Mundial e de suas ações começou a ser objeto de interpelação legislativa frequente. Cada rodada de negociação para a reposição de fundos à AID ensejou toda sorte de pressões e barganhas cruzadas entre os EUA e os demais doadores, no plano internacional, e entre o Tesouro, o Departamento de Estado e o Legislativo, no plano doméstico.

\section{0 "assalto à pobreza": teoria e resultados}

Até o início dos anos setenta, a área de pesquisa do Banco Mundial havia sido "pequena e subfinanciada", com pouca ou nenhuma influência no âmbito operacional. ${ }^{36}$ A nomeação de Hollis Chenery para o novo cargo de economistachefe em maio de 1970 foi o início de uma mudança importante que culminou na constituição de um departamento de pesquisa bastante bem equipado e financiado em termos materiais e humanos, cuja missão era elaborar uma base sólida de dados e conceitos que apoiasse a expansão das operações financeiras e desse sustentação ao protagonismo intelectual do Banco no âmbito do desenvolvimento.

Entre os anos 1968-73, a gestão McNamara oscilou entre diversos instrumentos para levar adiante a tal "cruzada contra a pobreza". ${ }^{37}$ Primeiro, o Banco insistiu no planejamento familiar e no controle populacional, a partir de um

${ }^{36}$ MASON, Edward e ASHER, Robert. The World Bank since Bretton Woods, op. cit., p. 467.

${ }^{37}$ FINNEMORE, Martha. Redefining development at the World Bank. In: COOPER, Frederick e PACKARD, Randall (eds.). International development and the social sciences. Essays on the history and politics of knowledge. $1^{\mathrm{a}}$ edição. Berkeley: University of California Press, 1997, p. 214-216. 
viés agudamente neomalthusiano que projetava o crescimento demográfico nos países do Terceiro Mundo como causa da perpetuação da miséria. Depois vieram o combate ao desemprego, a nutrição, a saúde e a educação. Em suma, ao lado dos projetos agrícolas, diversos outros projetos em áreas distintas pareceram constituir, em algum momento, o carro-chefe do Banco Mundial na área social, sem se firmarem como tal.

De fato, a consiga do "assalto à pobreza" careceu, durante o primeiro quinquênio da gestão McNamara, de dois elementos importantes: um enfoque que lhe desse suporte e racionalidade e um instrumento operacional que permitisse a sua replicação em larga escala. O Banco não tinha uma abordagem que conferisse coerência, para fora e para dentro, aos projetos que a instituição já vinha executando em agricultura, educação e desenvolvimento urbano. Também não tinha um instrumento preferencial que nucleasse a sua "cruzada contra a pobreza" e permitisse a aferição estatística dos seus resultados. Ou seja, não havia uma teoria nem um meio passível de replicação e avaliação econômica de resultados. Ambos surgiram somente no biênio 1973-74 com a definição da "pobreza rural absoluta" como alvo principal da intervenção do Banco, por meio dos novos projetos de "desenvolvimento rural integrado", e com a publicação do livro coordenado por Hollis Chenery Redistribuição com crescimento. Daí nasceu o enfoque orientado à pobreza (poverty-oriented approach) a partir do qual o Banco se firmou como paladino da luta contra a miséria em âmbito internacional. Cabe analisar esse processo mais detidamente, tendo em vista três ordens de fatores.

Em primeiro lugar, a consigna do "assalto à pobreza" foi enxertada no Banco pelo governo norte-americano como resposta às injunções da guerra fria, não sendo, portanto, resultante de uma evolução institucional endógena. ${ }^{38}$ Uma série de acontecimentos entre 1968-73 - como a experiência socialista no Chile, a eleição de Indira Gandhi, a guerra entre Índia e Paquistão e a fundação de Bangladesh, a nacionalização do petróleo e a reforma agrária no Peru, entre outros - se somaram à derrocada dos EUA no Vietnã, levando o governo estadunidense e seus aliados mais próximos a pressionarem as organizações multilaterais e bilaterais à busca de novas estratégias de atuação. Em todos os casos, o nacionalismo econômico, políticas distributivas e reformas redistributivas eram objeto de forte apelo popular. O ponto é que, para o establishment norte-americano, o fiel da balança política era o campesinato. Por essa razão, ganhar o apoio desse segmento, ou pelo menos desativar o seu protesto social, era prioritário. As palavras de Samuel

$\overline{{ }^{38} \text { KAPUR, Devesh et }}$ al. The World Bank: its first half century. History, op. cit., p. 222. 
Huntington, em seu clássico da teoria da modernização publicado originalmente em 1968, resumem bastante bem essa visão:

Para o sistema político, a oposição dentro da cidade pode ser perturbadora, mas não é letal. A oposição no interior é, porém, fatal. Quem controla o interior controla o país. (...) Se os camponeses aceitam e se identificam com o sistema existente, isso proporciona uma base estável ao sistema. Se os camponeses se opõem ativamente ao sistema, passam a ser os portadores da revolução (...). O camponês pode, assim, desempenhar um papel altamente conservador ou altamente revolucionário. ${ }^{39}$

Em segundo lugar, a construção do enfoque orientado à pobreza seria inconcebível sem a legitimidade crescente da crítica ao "efeito derrame" dentro do próprio paradigma dominante..$^{40}$ Em 1970, p. ex., durante a Sétima Conferência sobre Desenvolvimento de Cambridge, David Morse, diretor geral da OIT, denominou a perda de confiança no crescimento econômico como meio suficiente para reduzir a pobreza como a "derrocada do PIB". ${ }^{41}$ A OIT, em parceria com o Institute for Development Studies da Universidade de Sussex, conduziu sete estudos de caso (Colômbia, Sri Lanka, Quênia, Irã, Filipinas, Sudão e República Dominicana), durante o período de 1970 a 1975, que mostraram que, mesmo com taxas maiores de crescimento econômico, a desigualdade não estava diminuindo. ${ }^{42}$

Em terceiro lugar, a construção do enfoque orientado à pobreza esteve diretamente ligada a mudanças na política norte-americana de ajuda externa ao desenvolvimento. A pressão social e de setores do Congresso sobre o governo, cujo envolvimento na guerra do Vietnã a cada dia gerava níveis mais altos de desgaste político, levou, em 1973, à aprovação de uma nova legislação (Foreign Assistance Act, PL 93-189), mais conhecida como Novas Direções, que modificou a estrutura legal básica da ajuda externa norte-americana, bilateral e multilateral, reestruturando-a e reorientando-a para o atendimento direto às "necessidades humanas básicas". A nova diretriz tinha como foco a redução da "pobreza extrema" mediante a concessão de crédito para o aumento da produtividade de "pequenos agricultores". ${ }^{43}$ A rigor, não se tratava de uma novidade, mas sim da retomada, sob nova roupagem, de iniciativas postas em prática pelo governo estadunidense

${ }^{39}$ HUNTINGTON, Samuel. A ordem política nas sociedades em mudança. São Paulo e Rio de Janeiro: Editora da USP/Forense Universitária, 1975, p. 302.

${ }^{40}$ FINNEMORE, Martha. Redefining development at the World Bank, op. cit., p. 208-209.

${ }^{41}$ BUSTELO, Pablo. Teorías contemporáneas del desarrollo económico. $1^{\mathrm{a}}$ edição. Madri: Editorial Sintesis, 1999, p. 144.

42 Ibid, p. 251.

${ }^{43}$ AYRES, Robert. Banking on the poor: the World Bank and world poverty, op. cit., p. 9. 
desde os anos 1950 e 1960 com o Desenvolvimento de Comunidade e a Aliança para o Progresso. De todo modo, as Novas Direções impuseram ao Banco uma maior coerência entre a sua retórica pro-poor e a qualidade da sua carteira de projetos voltados para esse fim.

Internamente, um passo decisivo foi a definição da "pobreza absoluta" como unidade de análise e critério operacional. ${ }^{44}$ Esse movimento se consolidou no biênio 1972-73, culminando, em 1974, com a publicação do livro coordenado por Chenery. O discurso de McNamara em 1972 foi um marco dessa guinada:

Quando os privilegiados são poucos e os desesperadamente pobres são muitos, e quando a brecha entre ambos os grupos se aprofunda em vez de diminuir, é apenas uma questão de tempo até que seja preciso escolher entre os custos políticos de uma reforma e os riscos políticos de uma rebelião. Por este motivo, a aplicação de políticas especificamente encaminhadas para reduzir a miséria dos $40 \%$ mais pobres da população dos países em desenvolvimento é aconselhável não somente como questão de principio, mas também de prudência. ${ }^{45}$

No ano seguinte, em um discurso histórico em Nairóbi, McNamara reiterou a menção aos $40 \%$ mais pobres; dessa vez, porém, sua mensagem apareceu codificada numa estratificação da pobreza em duas categorias: relativa e absoluta. ${ }^{46}$ A novidade dava suporte operacional à identificação de "focos de pobreza" absoluta no meio rural, que deveriam, então, ser "atacados" mediante projetos de "desenvolvimento rural" voltados para o aumento da produtividade da terra de "pequenos agricultores" que financiassem a aquisição e a aplicação de pacotes tecnológicos. Ou seja, tratava-se de implementar uma "pequena revolução verde" em parcelas do campesinato. ${ }^{47}$ A concentração da propriedade da terra foi tomada como um dado ao qual os projetos deveriam se acomodar. ${ }^{48}$ Adicionalmente, McNamara propôs a realização de programas de obras rurais de pequeno e médio porte para gerar emprego temporário não-agrícola no campo a baixo custo para o contingente cada vez maior de trabalhadores rurais sem-terra.

${ }^{44}$ KAPUR, Devesh et al. The World Bank: its first half century. History, op. cit., p. 239-240.

${ }^{45}$ McNAMARA, Robert. Discurso ante la Junta de Gobernadores. Washington: The World Bank, 25 de setembro, 1972, p. 31.

${ }^{46}$ McNAMARA, Robert. Discurso ante la Junta de Gobernadores. Nairóbi: The World Bank, 24 de setembro, 1973, p. 27.

${ }^{47}$ FEDER, Ernest. La pequena revolución verde de McNamara. El proyecto del Banco Mundial para la eliminación del campesinado del Tercer Mundo. Comercio Exterior. Cidade do México: vol. 26, nº 7, julho, 1976, p. 793-794; GEORGE, Susan. O mercado da fome. $1^{\text {a }}$ edição. Rio de Janeiro: Paz e Terra, 1978, p. 238-239.

${ }^{48}$ AYRES, Robert. Banking on the poor: the World Bank and world poverty, op. cit., p. 104. 
Publicado no ano seguinte, Redistribuição com crescimento academizou o discurso de McNamara em Nairóbi e deu ao Banco um núcleo teórico que permitiu vender com mais eficácia o seu novo produto - o desenvolvimento rural integrado -, instituindo a "pobreza absoluta" e os "grupos-alvos" como categorias operacionais legítimas para as políticas públicas.

O livro partia da distinção entre pobreza absoluta e relativa, deixando de lado a desigualdade na distribuição de renda e a pobreza relativa e trazendo para o primeiro plano o aumento da renda e a redução da pobreza absoluta. A tese fundamental era a de que a redução da pobreza absoluta não era incompatível com o crescimento da economia. Como, então, aumentar a renda dos "pobres"? Chenery e seus colaboradores elencaram quatro estratégias distintas: a) a maximização do crescimento do PIB através do aumento das poupanças e de uma melhor alocação dos recursos, o que beneficiaria, acreditavam os autores, todos os grupos da sociedade; b) a reorientação do investimento para os grupos-alvo em "pobreza absoluta" sob a forma de educação, acesso ao crédito, obras públicas etc.; c) a redistribuição de renda ou consumo para os grupos-alvo através do sistema fiscal ou da transferência direta de bens de consumo; d) a redistribuição de ativos existentes para os segmentos mais pobres, por meio de políticas como a reforma agrária. ${ }^{49}$ A proposta central do livro consistia em "concentrar o investimento público no aumento da capacidade produtiva e dos rendimentos dos pobres", ${ }^{50} \mathrm{ou}$ seja, a segunda estratégia. As demais foram descartadas no todo ou em parte: a primeira por reforçar ainda mais a concentração de renda; a terceira por consumir em excesso recursos de maneira "não-produtiva"; a quarta pelo seu "alto custo de desorganização social e política" e a sua não-aplicabilidade em larga escala. ${ }^{51}$

A rigor, tratava-se de uma estratégia distributiva de tipo incremental, na medida em que se limitava a distribuir parte do crescimento econômico (rendas e ativos novos) mediante projetos e programas financiados através de captação de impostos e endividamento externo. Em tese, tais ações fomentariam o aumento da "produtividade dos mais pobres", de tal forma que, por meio da sua inserção mercantil, a renda deles se elevasse. Repartir um pedaço do crescimento do bolo, e não o bolo: era isso o que propunha o Banco Mundial. ${ }^{52} \mathrm{O}$ título do livro evocava o que, precisamente, era negado pelo seu conteúdo: a ideia de redistribuição. Por

${ }^{49}$ CHENERY, Hollis et al. Redistribución con crecimiento. $1^{\text {a }}$ edição. Madri: Tecnos, 1976, p. 76.

${ }^{50}$ Ibid, p. 78.

${ }^{51}$ Ibid, p. 78.

52 ASSMANN, Hugo. El 'progresismo conservador' del Banco Mundial. In: ASSMANN, Hugo (ed.). Banco Mundial: un caso de "progressismo conservador”. 1ª edição. San José: Departamento Ecuménico de Investigaciones, 1980, p. 11. 
outro lado, como Redistribuição com crescimento descartava qualquer concessão por parte dos setores dominantes, a sua estratégia incremental de distribuição carecia de uma teoria política. Assim, a coalizão capaz de impulsionar o enfoque proposto surgia, no texto, como um dado. Isso explica as exortações vazias de McNamara por "vontade política", "coragem" e "obrigação moral" dos mais ricos de "ajudar os pobres e os fracos". ${ }^{53}$

A ideia de que a superação da pobreza rural e urbana dar-se-ia pelo aumento da "produtividade dos pobres" tinha como premissa a ideia de que vivia em tais condições apenas quem não estivesse inserido em atividades consideradas produtivas e rentáveis. Tal proposição operava um triplo movimento: primeiro, apagava o caráter desigual e combinado das formas de exploração e, portanto, a "funcionalidade dos pobres" (desempregados, subempregados, pequenos agricultores etc.) para a acumulação capitalista; segundo, isolava a pobreza do conjunto das relações sociais, como se fosse um fenômeno em si mesmo; terceiro, reificava as modalidades mais predatórias de desenvolvimento capitalista, na medida em que explicava a pobreza como exclusão do progresso, e não como um dos seus resultados. ${ }^{54}$ Esse triplo movimento permitiu ao Banco fortalecer politicamente a consigna da luta contra a pobreza, ao fazê-la parecer autoexplicativa e legítima por si própria. Permitiu, também, eludir a questão dos baixos salários e da necessidade de criação de empregos, na medida em que deslocava o foco de análise para a qualidade da inserção atomizada dos indivíduos no mercado.

Ademais, o livro serviu para dar suporte à "pobretologia", ${ }^{5}$ i. e., à imposição da pobreza como unidade de análise, parâmetro legítimo e foco obrigatório para toda e qualquer iniciativa no âmbito da assistência ao desenvolvimento. A institucionalização da redução da pobreza como parte da agenda internacional esteve diretamente ligada ao envolvimento cada vez maior do Banco Mundial, a partir dos anos setenta, em pesquisa (em particular, análises de inputs-outputs e de custo-benefício), produção, compilação e disseminação de dados. Surgiu um corpo interno de conhecimento, ligando um documento a outro para sua evidência e argumentação, reforçando e amalgamando ideias e práticas. O Banco também passou a financiar a pesquisa local e a formar técnicos para fins de produção

53 McNAMARA, Robert. Discurso ante la Junta de Gobernadores. Nairóbi: 24 de setembro, 1973, op. cit., p. 6.

54 ASSMANN, Hugo. El 'progresismo conservador' del Banco Mundial, op. cit., p. 47; PAYER, Cheryl. El Banco Mundial y los pequeños agricultores. In: ASSMANN, Hugo (ed.). Banco Mundial: un caso de "progresismo conservador", op. cit., p. 140.

55 KAY, Cristóbal. Rural poverty and development strategies in Latin America. Journal of Agrarian Change. Londres: vol. 6, $\mathrm{n}^{\mathrm{o}}$ 4, 2006, p. 457. 
de dados e desenho de projetos ligados ao tema. ${ }^{56}$ A partir dessas iniciativas, constituiu-se todo um campo de pesquisa dedicado a essa temática.

\section{0 "assalto à pobreza" no meio rural e nas cidades}

Após a promoção da atividade agropecuária e agroindustrial para os mercados externo e interno, a redução da pobreza foi o segundo objetivo da política do Banco para o campo nos anos setenta.$^{57}$ Os projetos com essa finalidade foram, então, etiquetados como "desenvolvimento rural". Com ênfase no crescimento da produtividade da terra e em cultivos de maior valor comercial, tais projetos ambicionavam financiar parcelas de pequenos agricultores (proprietários) que tivessem potencial produtivo e capacidade de endividamento, embora fossem considerados pobres do ponto de vista da renda monetária auferida. Nenhum deles foi desenhado para alcançar trabalhadores sem-terra, nem orientados para posseiros, parceiros, meeiros e arrendatários, e, sim, para a camada superior do grupo-alvo. ${ }^{58} \mathrm{Ou}$ seja, não foram pensados ou direcionados para chegar aos "mais pobres dentre os pobres", ${ }^{59}$ muito menos para redistribuir renda e riqueza. ${ }^{60}$

No documento-guia sobre o tema, publicado em 1975, o desenvolvimento rural foi concebido como um conjunto de atividades que extrapolavam um setor específico e tinham o objetivo de aumentar a produtividade agrícola, as oportunidades de emprego e o nível de renda da população-alvo (em condições de pobreza absoluta), e também melhorar alimentação, moradia, saúde e educação básicas até padrões considerados minimamente aceitáveis. ${ }^{61}$ Porém, segundo a auditoria interna publicada pelo Departamento de Avaliação de Operações em 1988, os técnicos do Banco, na prática, definiram os projetos de desenvolvimento rural como aqueles em que ao menos $50 \%$ dos futuros "beneficiários" diretos estivessem abaixo da linha de pobreza. ${ }^{62}$ Ou seja, em vez de um conceito que combinasse

${ }^{56}$ GOLDMAN, Michael. Imperial nature: the World Bank and struggles for social justice in the age of globalization, op. cit., p. 77-81; FINNEMORE, Martha. Redefining development at the World Bank, op. cit., p. 208.

${ }^{57}$ KAPUR, Devesh et al. The World Bank: its first half century. History, op. cit., p. 412.

${ }^{58}$ VAN DE LAAR, Aart. The World Bank and the world's poor. World Development. Londres: vol. 4, n 10-11, 1976, p. 840; LIPTON, Michael e SHAKOW, Alexander. O Banco Mundial e a pobreza. Finanças \& Desenvolvimento. São Paulo: vol. 2, nº 2, 1982, p. 17.

${ }^{59}$ AYRES, Robert. Banking on the poor: the World Bank and world poverty, op. cit., p. 102.

${ }^{60}$ BANCO MUNDIAL. Desarrollo rural. Documento de politica sectorial, Washington: The World Bank, p. 20.

${ }^{61}$ BANCO MUNDIAL. Desarrollo rural. Documento de politica sectoria, op. cit., p. 4.

${ }^{62}$ BANCO MUNDIAL. Rural development. World Bank experience, 1965-86. Washington: Operations Evaluation Department, The World Bank, 1988, p. xiv. 
metas setoriais e subsetoriais dentro de uma área definida geograficamente, os operadores adotaram uma definição de desenvolvimento rural baseada no cálculo estrito da pobreza. A implementação em uma via única e simples foi a forma mais eficaz de responder à pressão institucional para "mover o dinheiro" com rapidez e, assim, aumentar o número de empréstimos e a cota de desenvolvimento rural na rubrica total da agricultura ${ }^{63}$ Isto alimentou um procedimento de fachada, pelo qual inúmeros projetos tradicionais de infraestrutura eram reetiquetados para que coubessem na definição prática de desenvolvimento rural. ${ }^{64}$

Atuando como um atacadista de crédito, o Banco constituiu-se no principal financiador externo para a agricultura, posição que manteve ao longo de toda a década de setenta. Com frequência, a velocidade com que autorizava empréstimos era superior (às vezes bastante superior) à capacidade de implementação dos estados. Isto alimentou a prática neocolonial da criação de autoridades especiais segregadas do restante da administração pública e dominadas por financiadores estrangeiros. A montagem desses nichos burocráticos para levar adiante os projetos contribuiu para fragmentar e dualizar a máquina pública ${ }^{65} \mathrm{Em}$ poucos anos, tais enclaves se tornaram contraprodutivos, em particular na África. ${ }^{66}$

De acordo com o documento setorial de 1975, desenvolvimento rural significava perseguir um conjunto articulado de metas setoriais e subsetoriais dentro de uma jurisdição geográfica específica. Nesse sentido, os projetos de desenvolvimento de área (area development) representariam o núcleo por excelência dessa proposta. ${ }^{67} \mathrm{Em}$ larga medida, eram tais projetos que o Banco começou a chamar de desenvolvimento rural integrado (DRI). ${ }^{68}$

Em regra, os projetos de DRI eram guiados por uma visão burocrática e homogeneizadora do mundo social, sem flexibilidade para adaptar seus componentes à diversidade local e sem a participação da população supostamente beneficiária nas decisões fundamentais.

A rigor, pouco se sabe sobre os resultados dos projetos de DRI. A missão de avaliá-los cabia ao Banco e aos governos, que pouco tinham essa prática, até porque, entre outras razões, a pressão social para o que fizessem era inexistente

${ }^{63}$ KAPUR, Devesh et al. The World Bank: its first half century. History, op. cit., p. 414.

${ }^{64}$ BANCO MUNDIAL. Rural development. World Bank experience, 1965-86, op. cit., p. xiv.

${ }^{65}$ VAN DE LAAR, Aart. The World Bank and the world's poor, op. cit., p. 845-846.

${ }^{66}$ LACROIX, Richard. Desarrollo rural integral en América Latina. Washington: Banco Mundial, Documento de Trabajo, $\mathrm{n}^{\circ}$ 7.165, 1985, p. 14; KAPUR, Devesh et al. The World Bank: its first half century. History, op. cit., p. 414.

${ }^{67}$ BANCO MUNDIAL. Rural development. World Bank experience, 1965-86, op. cit., p. xiv.

${ }^{68}$ LACROIX, Richard. Desarrollo rural integral en América Latina, op. cit., p. 17-18. 
ou insignificante. Devido ao imperativo de "mover o dinheiro", os técnicos do Banco atuavam como vendedores de projetos, de modo que a maior parte dos recursos operacionais eram gastos em atividades necessárias à concessão de empréstimos, pouco restando para supervisão e avaliação. ${ }^{69}$ Além disso, em função de suas implicações políticas, a avaliação era tomada - quando o era muito mais como uma atividade de relações públicas do que um trabalho sério de investigação. ${ }^{70}$ De acordo com uma avaliação do próprio Banco, os projetos tiveram um "impacto muito limitado" e um viés marcante em favor de "agricultores com maior potencial de produção". ${ }^{11}$ Além disso, considerando as próprias diretrizes de 1975 em matéria de desenvolvimento rural, pode-se estimar como significativa, no mínimo, a apropriação de recursos e benefícios auferidos por grupos sociais distintos dos "grupos-alvo". Literalmente:

Em muitos países é essencial evitar a oposição dos grupos poderosos e influentes da comunidade rural para que os programas [de desenvolvimento rural] não se vejam subvertidos a partir de dentro. Ao preparar os programas deve-se tomar em conta o sistema social prevalecente, se se quer lograr benefícios perduráveis para os pobres. Portanto, nos casos em que há um elevado grau de desigualdade econômica e social, pode ser otimista esperar que mais de $50 \%$ dos benefícios dos projetos possam ser canalizados para os grupos objetos do desenvolvimento, e com frequência, a proporção será muito menor. ${ }^{72}$

Após Nairóbi, ao mesmo tempo em que deslanchava os projetos de desenvolvimento rural, a gestão McNamara se engajou na procura por um instrumento análogo para o meio urbano, i. e., um tipo de projeto que pudesse ser replicado de forma rápida, que tivesse uma população-alvo mais ou menos bem definida e que servisse de veículo para investimentos considerados produtivos, e não apenas para transferências sociais. ${ }^{73} \mathrm{O}$ tema foi objeto do discurso de McNamara em 1975, mais uma vez numa perspectiva política explícita:

Entre os grupos urbanos de baixa renda, as frustrações se inflamam e são facilmente aproveitadas pelos extremistas políticos. Se as cidades não começarem a tratar de maneira mais

${ }^{69}$ Ibid, p. 14-15.

${ }^{70}$ Ibid, p. 25.

${ }^{71}$ Ibid, p. 23-24.

72 BANCO MUNDIAL. Desarrollo rural. Documento de política sectorial, op. cit., p. 49.

73 AYRES, Robert. Banking on the poor: the World Bank and world poverty, op. cit., p. 154; KAPUR, Devesh et al. The World Bank: its first half century. History, op. cit., p. 263. 
construtiva o problema da pobreza, esta pode muito bem começar a tratar de maneira mais destrutiva as cidades. Este não é um problema que admita demora por razões políticas. ${ }^{74}$

Diversos documentos setoriais foram publicados entre 1974 e 1976 e se criou um grupo de trabalho para assegurar a implementação do novo objetivo: minorar a pobreza urbana - absoluta, sempre. Focalização e produtividade eram as palavraschave. Os primeiros projetos do Banco, autorizados ainda em 1972, seguiam o enfoque de terrenos e serviços (sites and services), cujo objetivo era de prover uma abordagem replicável que conciliasse recuperação de custos máxima, sob a forma de cobrança de taxas, e subsídio público mínimo. Em outras palavras, o seu objetivo central era demonstrar a viabilidade financeira e política de um modelo da habitação urbana de baixo padrão que fosse autofinanciável. O procedimento básico consistia em limitar ao mínimo possível a provisão pública para a compra da terra e a construção de infraestrutura básica, deixando, aos novos proprietários, a responsabilidade e grande parte dos custos da autoconstrução das casas. Posto em prática pelo BID e pela Usaid desde o início dos anos sessenta, tal enfoque fornecia um meio para se explorar o trabalho não-pago, rebaixar o custo de reprodução da força de trabalho e alimentar o conformismo social através do acesso à propriedade. ${ }^{75}$ Além de problemas de ordem legal relacionados à compra dos terrenos, o enfoque sites and services mostrou-se não-replicável, porque a máxima recuperação de custos impunha que o padrão dos terrenos e da provisão de serviços fosse rebaixado a níveis tão aviltantes que eram precisos subsídios adicionais. ${ }^{76}$

Na tentativa de ampliar o grau de cobertura, acelerar a implementação e baixar custos, o Banco Mundial passou a priorizar, então, a "urbanização de favelas" (slum upgrading). O novo enfoque exigia o mínimo de demolição física e reassentamento de pessoas, com a vantagem de servir plenamente à canonização da habitação favelada, ao discurso do "ajudar os pobres a ajudarem a si próprios" e à ilusão incremental do "construa-você-mesmo". ${ }^{77}$

A abordagem da "urbanização de favelas", no entanto, logo mostrou não ter resolvido o problema da focalização nos segmentos mais pobres, em parte porque o próprio Banco não abria mão da recuperação de custos. Para rebater

\footnotetext{
${ }^{74}$ McNAMARA, Robert. Discurso anual ante la Junta de Gobernadores. Washington: 1 de setembro, 1975, p. 36.

75 ARANTES, Pedro Fiori. O ajuste urbano: as políticas do Banco Mundial e do BID para as cidades latino-americanas. Dissertação de mestrado, Faculdade de Arquitetura e Urbanismo, Universidade de São Paulo, 2004, p. 33.

${ }^{76}$ KAPUR, Devesh et al. The World Bank: its first half century. History, op. cit., p. 317-318.

${ }^{77}$ DAVIS, Mike. Planeta Favela. $1^{\text {a }}$ edição. São Paulo: Boitempo, 2006, p. 80-81.
} 
a pressão pelo aliviamento da cobrança aos supostos beneficiários, o Banco insistia na possibilidade de desenvolver projetos que fossem, ao mesmo tempo, economicamente viáveis e focalizados, desde que tivessem desenho "apropriado" e gestão "competente e eficaz". ${ }^{78}$

Como a estratégia de moradia urbana de baixos padrões corria na direção contrária à dos códigos legais de habitação existentes na grande maioria dos países prestatários, o Banco Mundial reforçou ainda mais o investimento na "construção institucional”, impulsionando a criação de diversas agências autônomas ou autoridades nacionais ou estaduais responsáveis pela política habitacional. Não raro, tais organismos ajudaram a blindar as decisões-chave em matéria de política urbana contra o voto popular. ${ }^{79}$

Depois de Nairóbi, o Banco Mundial também se envolveu com o debate sobre necessidades básicas. A discussão apareceu em 1976 como uma suposta redefinição do enfoque orientado à pobreza, dando peso à "necessidade" como critério de decisão para a delimitação dos projetos e a alocação de recursos. A OIT havia lançado o enfoque na conferência "Emprego, crescimento e necessidades básicas" no mesmo ano, afirmando que a luta contra a pobreza devia ser concebida e travada sob aquela abordagem. ${ }^{80}$

O novo enfoque rivalizava com o de Chenery, sem, no entanto, suplantá-lo. Internamente, a gestão McNamara debateu durante os cinco ou seis anos seguintes quais seriam as necessidades básicas desejáveis ou possíveis e como justificá-las em termos de custo/benefício e assumir a responsabilidade de que o crescimento não seria prejudicado. ${ }^{81}$ Afinal, uma das vigas de sustentação do discurso de McNamara era a negação de trade-offs entre crescimento econômico e redução da pobreza (ou, no caso, satisfação de necessidades básicas). O debate não chegou a lugar algum e pouco se traduziu em projetos ou componentes de projetos. ${ }^{82}$

O objetivo do novo enfoque não era negar a teoria do derrame. ${ }^{83}$ Como explicou McNamara: "se as pessoas que vivem na pobreza absoluta tivessem que esperar que os benefícios do crescimento econômico global fossem filtrados até elas, o ritmo em que melhorariam seus rendimentos e nível de bem-estar seria

\footnotetext{
${ }^{78}$ KAPUR, Devesh et al. The World Bank: its first half century. History, op. cit., p. 319.

${ }^{79}$ DAVIS, Mike. Planeta Favela, op. cit., p. 76.

${ }^{80}$ KAPUR, Devesh et al. The World Bank: its first half century. History, op. cit., p. 265-267.

${ }^{81}$ AYRES, Robert. Banking on the poor: the World Bank and world poverty, op. cit., p. 85-89.

${ }^{82}$ KAPUR, Devesh et al. The World Bank: its first half century. History, op. cit., p. 265-267.

${ }^{83}$ STREETEN, Paul et al. Lo primero es lo primero: satisfacer las necesidades básicas en los países en desarrollo. $1^{\mathrm{a}}$ edição. Madri: Tecnos/Banco Mundial, 1986, p. 95-105.
} 
intoleravelmente pequeno" ${ }^{84} \mathrm{Ou}$ seja, tratava-se tão-somente de complementar, por meio de ações variadas, o gotejamento que, em tese, ocorreria numa velocidade então politicamente inaceitável.

Tal como acontecia com a redução da pobreza, a satisfação das necessidades básicas também era tomada como um objeto isolado do conjunto das relações sociais e da política econômica, desconsiderando-se o desemprego e o rebaixamento da remuneração da força de trabalho ${ }^{85}$ Com efeito, a nova proposta se acomodava bem à abordagem de aliviamento da pobreza absoluta pela via do aumento da produtividade do trabalho e da inserção mercantil. Seu objetivo não era, evidentemente, mudar o mundo no qual os "pobres" viviam, mas, sim, melhorar, pontual e marginalmente, os termos pelos quais eles nele se inseriam. ${ }^{86}$

Todavia, a movimentação em torno das necessidades básicas acabou por consagrar saúde e educação primárias como áreas abertas ao investimento produtivo (lucrativo) nos países da periferia. O Banco seguiu essa linha, destacando-se, desde o primeiro momento, por subordiná-las aos imperativos políticos do aliviamento da pobreza absoluta e da reformulação e redução dos gastos com políticas sociais. No final de 1979, McNamara criou o Departamento de População, Saúde e Nutrição, o que permitiu a autorização de empréstimos exclusivamente para a saúde - antes, o setor figurava apenas como um componente em projetos de desenvolvimento rural e urbano e planejamento familiar -, abrindo um campo novo e amplíssimo de atuação. Enquanto isso, a entrega do Prêmio Nobel de economia para Schultz e Lewis, no mesmo ano, serviu para entronizar tardiamente o conceito de capital humano aplicado à educação básica na agenda do Banco Mundial. Os governos dos EUA e do Reino Unido, em especial, apoiaram entusiasticamente, no Conselho de Governadores do Banco, a ênfase na educação básica. Em 1980, o Relatório sobre Desenvolvimento Mundial chancelou as duas novas prioridades na área social. Gestavam-se, naquele momento, as coordenadas principais de um modelo de política social que se tornaria hegemônico uma década depois, centrado não mais no acesso a ativos produtivos físicos, mas sim na formação de capital humano.

Apesar de todas as exortações em prol da "luta contra a pobreza extrema", ao longo da gestão McNamara, os empréstimos do Banco para projetos com algum componente (não necessariamente majoritário) “orientado à pobreza” oficialmente

\footnotetext{
${ }^{84}$ McNAMARA, Robert. Discurso anual ante la Junta de Gobernadores. Washington: The World Bank, 30 de setembro, 1980, p. 34

${ }^{85}$ ASSMANN, Hugo. El 'progresismo conservador' del Banco Mundial, op. cit., p. 49-50.

${ }^{86}$ AYRES, Robert. Banking on the poor: the World Bank and world poverty, op. cit., p. 89.
} 
não ultrapassaram um terço do total. Entretanto, esta cifra está superestimada, pois o staff exagerava o grau de cobertura dos projetos, aumentando o número de beneficiários considerados pobres, uma vez que a ascensão profissional dependia do volume de empréstimos sob supervisão de cada funcionário. ${ }^{87}$

Contudo, quando comparados à magnitude do investimento público realizado pelos estados clientes, os empréstimos do Banco sempre representaram uma quantia irrisória. Aliás, McNamara logo descobriu isso. Afinal, como secretário de Defesa dos EUA, ele contara com um orçamento anual de mais de US\$70 bilhões, mas quando chegou à presidência do Banco, viu-se diante de uma carteira que totalizava pouco mais de US\$ 1 bilhão ao ano. ${ }^{88}$ Para ele, estava claro que a atuação do Banco só podia provocar algum impacto no âmbito da formação de ideias e da assistência técnica. Assim, o financiamento funcionava mais como um veículo ou alavanca para a reorientação do gasto público e a remodelagem das políticas estatais. ${ }^{89}$

Ora, se os empréstimos para projetos orientados à pobreza mal representaram um terço do total financiado, pode-se afirmar que o impacto direto de tais projetos foi insignificante. Por outro lado, tanto no meio rural como no meio urbano, os projetos do Banco induziram mudanças na composição e na destinação do gasto público, na medida em que, para cada empréstimo contratado com o Banco, os governos tinham de desembolsar uma contrapartida financeira, em geral muito maior; depois, precisavam pagar o Banco, tido sempre como credor preferencial, e em moeda forte. Além disso, os projetos financiados pelo Banco Mundial forneceram parâmetros e condições para a redefinição de políticas setoriais e sociais em dezenas de países. Em muitos casos, agências e órgãos da administração pública responsáveis pela regulação de setores inteiros da economia foram erguidos a partir de empréstimos e/ou assessoria técnica do Banco. Nas áreas do desenvolvimento rural e urbano, por exemplo, não raro a replicabilidade dos projetos era garantida pela internalização de modelos e procedimentos produzidos e difundidos pelo Banco, o que, na prática, acabava por dispensar a contratação de empréstimos. Com frequência, esse processo teve conotações políticas reativas e assumiu uma direção conservadora, na medida em que serviu para que governos eludissem a pressão popular por reformas redistributivas,

${ }^{87}$ KAPUR, Devesh et al. The World Bank: its first half century. History, op. cit., p. 339.

${ }^{88}$ CAUFIELD, Catherine. Masters of illusion: the World Bank and the poverty of nations. $1^{\mathrm{a}}$ edição. Nova Iorque: Henry Holt, 1996, p. 97-98; GOLDMAN, Michael. Imperial nature: the World Bank and struggles for social justice in the age of globalization, op. cit., p. 74.

${ }^{89}$ KAPUR, Devesh et al. The World Bank: its first half century. History, op. cit., p. 271. 
como a reforma agrária. Por outro lado, é imensa a lista de projetos financiados ou apoiados pelo Banco que provocaram impactos altamente negativos do ponto de vista socioambiental..$^{90}$

\section{Endividamento acelerado, fugas para frente e início do ajustamento estrutural}

De 1973 a 1979, uma série de eventos agravou a instabilidade política no sistema internacional. A lista é longa: a eclosão de golpes militares e massacres no Chile, na Argentina e em Uganda, o escândalo do Watergate e a renúncia de Nixon, a guerra de secessão do Paquistão, a guerra do Yom Kipur entre Israel e as forças de Egito e Síria, o regime ditatorial do Khmer Vermelho no Camboja, a Revolução dos Cravos em Portugal, a derrocada da ditadura na Grécia, a crise da ditadura franquista na Espanha, a revolução sandinista na Nicarágua e as guerras civis no Líbano, em Angola, no Zaire, na Etiópia e em muitos outros países africanos (em alguns casos, com a presença militar ativa da URSS). ${ }^{91}$

A instabilidade no plano político internacional se somava à instabilidade econômica. De um lado, desde o final dos anos sessenta, as tensões no sistema monetário internacional tornavam a manutenção da convertibilidade do dólar em ouro cada vez mais difícil para os EUA. Como resposta, os EUA romperam unilateralmente com o regime monetário de Bretton Woods, mediante uma sequência de medidas praticadas pelo governo Nixon: em 1971, o corte da ligação entre o dólar e o ouro; em 1973, o abandono do sistema de paridades fixas, mas ajustáveis, em favor de taxas de câmbio flutuantes; em 1974, o fim das restrições ao fluxo de capitais nos EUA..$^{92}$ Essa movimentação fez parte da estratégia de destruição das regras que limitavam o domínio dos EUA sobre a política monetária internacional, por meio da transformação do regime monetário baseado no padrão ouro-dólar num regime baseado exclusivamente no padrão dólar. ${ }^{93}$ De outro lado, os países centrais

${ }^{90}$ A primeira e principal obra a investigar e denunciar os impactos socioambientais dos grandes projetos financiados pelo Banco Mundial foi a de RICH, Bruce. Mortgaging the Earth: the World Bank, environmental impoverishment, and the crisis of development. $1^{\mathrm{a}}$ edição. Boston: Beacon Press, 1994.

${ }^{91}$ KAPUR, Devesh et al. The World Bank: its first half century. History, op. cit., p. 273; VELASCO E CRUZ, Sebastião. Trajetórias: capitalismo neoliberal e reformas econômicas nos países da periferia. $1^{a}$ edição. São Paulo: Editora Unesp, 2007, p. 378-380.

92 TABB, William. Economic governance in the age of globalization. $1^{\mathrm{a}}$ edição. Nova Iorque: Columbia University Press, 2004, p. 82-83; BRENNER, Robert. O boom e a bolha: os Estados Unidos na economia mundial. $1^{\text {a }}$ edição. Rio de Janeiro: Record, 2003, p. 67-73; VELASCO E CRUZ, Sebastião. Trajetórias: capitalismo neoliberal e reformas econômicas nos países da periferia, op. cit., p. 364-65.

${ }^{93}$ GOWAN, Peter. A roleta global: uma aposta faustiana de Washington para a dominação do mundo. $1^{\text {a }}$ edição. Rio de Janeiro/São Paulo: Record, 2003, p. 45-50. 
sofriam a combinação de inflação, baixo crescimento e aumento do desemprego - em particular, após o primeiro choque do preço do petróleo, impulsionado no final de 1973 pela Opep - e respondiam, cada vez mais, com políticas defensivas do ponto de vista comercial e monetário. Por sua vez, alguns poucos países da periferia (como Brasil, México, Coreia do Sul e Taiwan) seguiam com altas taxas de crescimento econômico ao longo de toda a década, à custa de um endividamento externo contraído em ritmo galopante, oriundo do acesso ao crédito farto e barato oferecido por bancos privados internacionais encarregados de reciclar a renda petrolífera. Enquanto isso, a grande maioria dos países da periferia não-exportadores de petróleo empobrecia ou apresentava taxas de crescimento baixas. ${ }^{94}$

Por tudo isso, dentro do seu campo de ação, em que a estabilidade política e econômica estava sob ameaça, o Banco Mundial se concentrou no apoio a governos afinados e na concessão de empréstimos que viabilizassem sucessivas fugas para frente..$^{95}$

Por outro lado, o Banco impôs sanções a governos que promoviam políticas redistributivas. Os pedidos de empréstimo feitos pelo Chile, por exemplo, foram negados enquanto Allende esteve no poder e imediatamente autorizados após o golpe de setembro de $1973 .{ }^{96}$ Da mesma maneira, governos que adotaram medidas confiscatórias contra a propriedade privada - em particular contra ativos de empresas norte-americanas e/ou europeias - sofreram retaliações, como os da Argélia, do Peru, da Guiné e, depois da revolução sandinista, da Nicarágua. Quando ativos de empresas não-ocidentais foram objeto de expropriação (como em Uganda, p. ex.), o Banco não fez objeção. ${ }^{97}$

Depois do segundo choque do preço do petróleo em 1979, o Banco Mundial passou a concentrar ainda mais a sua carteira de empréstimos em modalidades que permitissem desembolsos elevados, apoiassem o balanço de pagamentos e servissem à obtenção de divisas que possibilitassem a rolagem dos débitos e a manutenção da espiral de endividamento externo. Nessa direção, as somas emprestadas dobraram entre os anos fiscais de 1978 e 1981, concentrando-se em alguns clientes preferenciais, todos altamente endividados. ${ }^{98}$ Os projetos "so-

${ }^{94}$ KAPUR, Devesh et al. The World Bank: its first half century. History, op. cit., p. 321.

${ }^{95}$ KAPUR, Devesh et al. The World Bank: its first half century. History, op. cit., p. 323-24.

${ }^{96}$ BROWN, Bartram S. The United States and the politicization of the World Bank. $1^{\mathrm{a}}$ edição. Londres e Nova Iorque: Kegan Paul International, 1992, p. 157-159; KAPUR, Devesh et al. The World Bank: its first half century. History, op. cit., p. 300-01.

${ }^{97}$ KAPUR, Devesh et al. The World Bank: its first half century. History, op. cit., p. 326.

${ }^{98}$ McNAMARA, Robert. Discurso anual ante la Junta de Gobernadores. Washington: The World Bank, 30 de setembro, 1980, p. 33. 
ciais", que até então haviam representado uma fração minoritária da carteira do Banco, passaram a representar menos ainda, e a consigna do "assalto à pobreza" gradualmente deixou de figurar no centro do discurso de McNamara.

Àquela altura, sob os efeitos do segundo choque do preço do petróleo e do aumento brusco da taxa de juro norte-americana, ambos em 1979, o Banco concentrava a sua atuação político-intelectual em um objetivo bem definido: firmar a proposta de "ajustamento estrutural" como meio necessário para adaptar e enquadrar os países endividados às novas condições da economia internacional. No biênio 1980-81, o tema esteve no centro da movimentação do Banco, seguindo de perto a evolução do quadro político e econômico internacional e a mudança mais geral na correlação de forças entre capital e trabalho. Cabe recuperar as linhas centrais desse processo.

Em 1978, saiu o primeiro Relatório sobre o Desenvolvimento Mundial (RDM), desde então a publicação anual mais importante do Banco. Centrado na ideia de "interdependência", o relatório dava destaque ao processo de endividamento externo através do qual grande parte dos países da periferia vinha financiando seu crescimento econômico, limitando-se a recomendar mudanças no perfil das dívidas (prazos maiores de vencimento) e nas estruturas de crédito (acesso a mercados de títulos de longo prazo e maior equilíbrio entre o financiamento de fontes privadas e públicas).$^{99}$ Por outro lado, embora ressaltasse a necessidade de políticas industrial e comercial ativas, o relatório distinguia duas estratégias de desenvolvimento: a "orientada para dentro" (inward-oriented), baseada na industrialização por substituição de importações, e a "orientada para fora" (outward-oriented), baseada na promoção das exportações. Enquanto a primeira era vista como sinônimo de fracasso, a segunda despontava como altamente promissora. Esse tipo de crítica já prefigurava a virada político-intelectual de fundo na agenda do Banco, consubstanciada no ataque neoclássico às estratégias econômicas de estilo nacional-desenvolvimentista.

No RDM 1979, o Banco reproduziu a mesma mensagem fundamental do ano anterior, qual seja, a de que o endividamento externo da periferia era parte do processo de ajustamento global necessário para responder aos desequilíbrios crescentes nos balanços de pagamentos, em particular dos países importadores de petróleo. ${ }^{100}$

\footnotetext{
${ }^{99}$ BANCOMUNDIAL.Informe sobre elDesarrollo Mundial. Washington:The WorldBank, 1978, p. 27. ${ }^{100}$ BANCO MUNDIAL. Informe sobre el Desarrollo Mundial. Washington: The World Bank, 1979, p. $15-20$.
} 
Estava-se no início do segundo choque internacional do petróleo de 1979-80. Em janeiro de 1979, a revolução islâmica liderada pelo aiatolá Khomeini derrubara o regime monárquico do xá Reza Pahlevi, apoiado ostensivamente pelos EUA, e obrigara as companhias petrolíferas estrangeiras estabelecidas no país a aceitarem uma renegociação ampla dos contratos. ${ }^{101}$ No ano seguinte, o Iraque, sob o comando de Saddam Hussein e com suporte político-militar dos EUA, atacou o novo regime xiita iraniano, iniciando uma guerra sangrenta que duraria oito anos. A produção de petróleo do Irã, então segundo maior exportador, ficou paralisada, elevando o preço do barril a um patamar sem precedentes.

Ao mesmo tempo, em outubro de 1979, o Federal Reserve, sob o comando de Paul Volcker, aumentou bruscamente a taxa de juro dos EUA, com o fim de conter a inflação doméstica e impulsionar a retomada da supremacia do dólar no sistema monetário internacional. Combinada à liberalização do fluxo de capitais, o "golpe de 1979"102 forçou a sobrevalorização do dólar e redirecionou a liquidez internacional para os EUA, submetendo a política econômica de todos os demais países capitalistas, concorrentes e aliados, a um ajuste recessivo sincronizado com a política estadunidense. Em pouco tempo, a flutuação das taxas de juro e câmbio voltou a estar atrelada ao dólar e, por meio dela, o movimento da liquidez internacional foi subordinado à política fiscal norte-americana. Os títulos da dívida pública dos EUA se tornaram o ativo líquido por excelência da economia internacional, obrigando os detentores de excedentes financeiros a adquiri-los. Alemanha e Japão — os dois países que, depois dos Estados Unidos, tinham importância estratégica na ordem capitalista — tiveram as suas políticas econômicas enquadradas. Estava em marcha a "diplomacia do dólar forte". ${ }^{103}$

Em maio de 1979, McNamara anunciou a criação de um novo instrumento financeiro, o empréstimo de ajustamento estrutural. ${ }^{104}$ De desembolso rápido e orientado para políticas, e não para projetos, tinha o objetivo de financiar o aumento das exportações e o déficit no balanço de pagamentos, sobretudo de países importadores de petróleo. A autorização desse tipo de empréstimo estava condicionada à realização, pelo prestatário, de um programa de estabilização

\footnotetext{
${ }^{101}$ HOBSBAWM, Eric. Era dos extremos. O breve século XX - 1914-1991. $1^{\text {a }}$ edição. São Paulo: Companhia das Letras, 1995, p. 440-441.

${ }^{102}$ DUMÉNIL, Gérard e LÉVY, Dominique. Crisis y salida de la crisis: orden y desorden neoliberales. $1^{\mathrm{a}}$ edição. México DF: Fondo de Cultura Económica, 2007.

${ }^{103}$ TAVARES, Maria da Conceição. A retomada da hegemonia norte-americana. In: TAVARES, Maria da Conceição e FIORI, José Luís (orgs.). Poder e dinheiro: uma economia política da globalização. $1^{\text {a }}$ edição. Petrópolis: Vozes, 1997, p. 27-53.

${ }^{104}$ KAPUR, Devesh et al. The World Bank: its first half century. History, op. cit., p. 1227.
} 
acordado previamente com o FMI e de um pacote de reformas na política macroeconômica, ambos voltados para adequar a economia doméstica ao novo ambiente externo e manter o pagamento do serviço da dívida.

A confluência do segundo choque do petróleo e da reviravolta da política monetária norte-americana com a queda dos preços das matérias-primas aumentou sensivelmente o custo da dívida externa dos países da periferia que vinham financiando o seu crescimento econômico mediante poupança externa. Em setembro de 1980, no seu último discurso anual perante o Conselho de Governadores do Banco Mundial, McNamara insistiu que as mudanças em curso na economia mundial eram "permanentes", razão pela qual o ajustamento dos países endividados às novas condições deveria ser de "larga duração". ${ }^{105} \mathrm{O}$ financiamento externo, a seu ver, deveria ser utilizado, a partir de então, como instrumento de apoio ao ajuste, e não como seu substituto - ou seja, como financiador de novas fugas para frente. Nesse sentido, caberia ao Banco concentrar sua atuação mais no ambiente de políticas econômicas e menos em projetos.

Não se pode perder de vista o fato de que o final do mandato de McNamara coincidiu com uma mudança radical na economia política internacional. Com o início dos governos Thatcher (1979) e Reagan (1981), a atmosfera política mundial sofreu uma guinada liberal-conservadora brusca e consistente. Desde a primeira hora e da forma mais agressiva, o governo Thatcher traduziu a ofensiva do capital como programa político, atacando o movimento sindical, os direitos sociais e todo tipo de política econômica de inspiração keynesiana e social-democrata. ${ }^{106} \mathrm{Na}$ mesma linha seguiu o governo Reagan, com o objetivo de restaurar e reconfigurar o poder de classe dos capitalistas no âmbito doméstico. ${ }^{107}$ Para essa nova direita, a política social do capitalismo nos anos 1950 e 1960 havia criado uma espécie de socialismo; não mais apoiado, desde 1973, pelo crescimento econômico, finalmente chegara a hora de aniquilá-lo. ${ }^{108}$ Ao mesmo tempo, no plano internacional, o eixo anglo-americano imediatamente passou a impulsionar políticas desregulacionistas, em detrimento de modalidades de política monetária, cambial e fiscal associadas ao protecionismo, à expansão do mercado interno e à regula-

\footnotetext{
${ }^{105}$ McNAMARA, Robert. Discurso anual ante la Junta de Gobernadores. Washington: 30 de setembro, 1980, p. 9-10.

${ }^{106}$ LEYS, Colin. A política a serviço do mercado: democracia neoliberal e interesse público. $1^{\mathrm{a}}$ edição. Rio de Janeiro: Record, 2004.

${ }^{107}$ DUMÉNIL, Gérard e LÉVY, Dominique. Crisis y salida de la crisis: orden y desorden neoliberales, op. cit.; HARVEY, David. Breve historia del neoliberalismo. $1^{\text {a }}$ edição. Madri: Akal, 2007.

${ }^{108}$ HOBSBAWM, Eric. Era dos extremos. O breve século XX-1914-1991, op. cit., p. 245.
} 
ção estatal sobre a atividade econômica. Paralelamente, a "diplomacia do dólar forte" combinada com a ofensiva político-militar liderada pelo governo Reagan contra a URSS - a "segunda guerra fria" - consubstanciaram um movimento mais amplo de recomposição da hegemonia norte-americana no sistema internacional.

O primeiro empréstimo de ajustamento estrutural, de US\$ 200 milhões, foi aprovado pelo Banco em março de 1980 para a Turquia e representou, na visão do Banco, um "protótipo" para os seguintes. ${ }^{109} \mathrm{O}$ Banco mantinha relações estreitas com políticos e altos quadros do Estado turco, em particular após o início da gestão McNamara, e viu no golpe militar de janeiro de 1980 a oportunidade para a execução de um programa duro de ajustamento. ${ }^{110} \mathrm{O}$ novo governo pôs em prática uma agenda afinada com as prescrições do Banco, orientada, entre outros objetivos, para a redução do déficit fiscal, a redução do investimento público, o aumento de incentivos às exportações e a gestão da dívida externa, segundo as prescrições do Banco Mundial. A Turquia já ocupava um lugar especial no tabuleiro geopolítico internacional pela sua localização estratégica. Diante da invasão soviética no Afeganistão e da revolução iraniana, tornou-se ainda mais importante para os EUA assegurar a estabilidade do país dentro do seu campo de influência, mediante o apoio ostensivo ao golpe e ao novo regime. O Banco Mundial integrou-se a essa estratégia, fornecendo uma sequência de empréstimos para ajustamento estrutural nos anos seguintes. ${ }^{111}$ De uma tacada, pois, a ação do Banco serviu aos objetivos geopolíticos dos EUA e ao início do enquadramento dos países da periferia.

No ano seguinte, o ajustamento estrutural foi o tema principal do RDM 1981. O relatório identificou diversos fatores responsáveis pelo estrangulamento dos países endividados, como a alta das taxas de juros reais, a queda da receita comercial dos países exportadores de commodities agrícolas, a recessão mundial, o aumento da proporção de empréstimos contratados a taxas de juros variáveis e o aumento do débito pendente com bancos comerciais (de 49,6\% em 1975 para 61,5\% em 1978). Apesar disso, o Banco afirmou que não havia um problema de endividamento generalizado e continuou a dar previsões otimistas - e erradas sobre o fluxo de capital privado para a periferia nos anos seguintes. A instituição voltou a encorajar o uso da poupança externa para que os países endividados

\footnotetext{
${ }^{109}$ KAPUR, Devesh et al. The World Bank: its first half century. History, op. cit., p. 548.

${ }^{110}$ TOUSSAINT, Eric. Banco Mundial: el golpe de Estado permanente. $1^{\mathrm{a}}$ edição. Madri: El Viejo Topo, 2006, p. 103.

${ }^{111}$ De 1980 a 1984, o Banco autorizou 32 empréstimos de ajustamento estrutural que totalizaram US\$ 4,390 bilhões, dos quais US\$ 1,555 bilhão, nada menos que $35 \%$, foram para a Turquia. Cf. MOSLEY, Paul et al. Aid and power: the World Bank and policy-based lending. $1^{\text {a }}$ edição. Londres: Routledge, vol. 1, 1991, p. 39.
} 
se ajustassem interna e externamente às novas condições da economia mundial, descritas como "permanentes".

Entre 1980 e 1981, pois, o Banco assumiu um papel de liderança políticointelectual ao introduzir, com sucesso, o tema do ajustamento estrutural no topo da agenda política internacional e no centro do debate econômico. ${ }^{112}$

O programa de ajustamento estrutural do Banco Mundial consistia, em linhas gerais, na mesma agenda monetarista aplicada pelo FMI desde os anos sessenta. ${ }^{113}$ No âmbito das políticas macroeconômicas, tratava-se de: liberalizar o comércio, alinhar os preços ao mercado internacional e baixar tarifas de proteção; desvalorizar a moeda; fomentar a atração de investimento externo e a livre circulação de capitais; promover a especialização produtiva e expandir as exportações, sobretudo agrícolas. No âmbito das políticas sociais e da administração estatal, o ajuste tinha como meta central a redução do déficit público, especialmente por meio de medidas como: a) o corte de gastos com pessoal e custeio da máquina administrativa; b) a redução drástica ou mesmo a eliminação de subsídios ao consumo; c) a redução do custo per capita dos programas, a fim de ampliar o grau de cobertura; d) a reorientação da política social para saúde e educação primárias, mediante a focalização do gasto na parcela da população em condições de "pobreza absoluta". Todo esse conjunto de medidas figurou, de um modo ou de outro, nos RDMs de 1978 a 1982 como prescrições de políticas econômicas e setoriais consideradas responsáveis.

Contudo, desde o início, a perspectiva do Banco sinalizava um movimento político-ideológico mais amplo que ultrapassava os pacotes de estabilização monetária do FMI e se ligava à nova divisão de trabalho entre "estado" e "mercado" que emergia como expressão de um duplo movimento: de um lado, a pressão liberalizadora encabeçada pela Inglaterra de Thatcher e pelos EUA de Reagan; de outro, a mudança mais geral na correlação de forças entre capital e trabalho. ${ }^{114}$ Não por acaso, o RDM de 1978 já esboçava os contornos gerais da crítica neoclássica ao estilo de desenvolvimento baseado na substituição de importações. Além disso, todas as políticas prescritas para reduzir o déficit público

${ }^{112}$ STERN, Nicholas e FERREIRA, Francisco. The World Bank as “intellectual actor". In: KAPUR, Devesh et al. (eds.). The World Bank: its first half century - Perspectives. Washington DC: Brookings Institution Press, vol. 2, 1997, p. 541.

${ }^{113}$ LICHTENSZTEJN, Samuel e BAER, Mônica. Fundo Monetário Internacional e Banco Mundial: estratégias e politicas do poder financeiro, op. cit., p. 196-199; BROWN, Michael Barrat. Africa's choices after thirty years of the World Bank. $1^{\text {a }}$ edição. Boulder: Westview Press, 1995, p. 68-69.

${ }^{114}$ HARVEY, David. Breve historia del neoliberalismo, op. cit.; GOWAN, Peter. A roleta global: uma aposta faustiana de Washington para a dominação do mundo, op. cit. 
atacavam, primeiro e preferencialmente, direitos sociais e trabalhistas que, até então, configuravam certo balanço de poder entre capital e trabalho.

Os empréstimos do Banco e, sobretudo, a sua anuência ao padrão de crescimento financiado pela oferta indiscriminada de crédito externo (público e privado), contribuíram, direta e indiretamente, para o endividamento da grande maioria das economias da América Latina e do Caribe, da África e, em menor grau, da Ásia. ${ }^{115}$ Após 1973, com o aumento do preço do petróleo e de outras matérias-primas, a política de "mover o dinheiro" como meio de influência viabilizou sucessivas fugas para frente que, por um lado, ajudaram a viabilizar politicamente regimes ditatoriais e, por outro, sustentaram a reprodução de um padrão de acumulação calcado no aumento da dependência externa e na concentração de renda e riqueza. Durante os anos fiscais de 1978-81, as somas emprestadas pelo Banco Mundial dobraram, concentrando-se em alguns poucos clientes preferenciais. ${ }^{116} \mathrm{~A}$ tabela 3 identifica quais eram os países mais endividados com o Banco quando McNamara deixou a presidência da instituição, um ano antes do estouro da crise da dívida externa.

\section{Tabela 3. Dez principais mutuários do BIRD e da AID - 30 de junho de 1981}

\begin{tabular}{|l|c|c|c|}
\hline Mutuários do BIRD & $\begin{array}{c}\text { Empréstimos } \\
\text { em mora }\end{array}$ & Mutuários da AID & $\begin{array}{c}\text { Empréstimos } \\
\text { em mora }\end{array}$ \\
\hline 1. Brasil & 9.73 & 1. Índia & 40.33 \\
\hline 2. México & 7.92 & 2. Bangladesh & 7.41 \\
\hline 3. Indonésia & 6.59 & 3. Paquistão & 5.93 \\
\hline 4. Coreia do Sul & 5.63 & 4. Egito & 4.01 \\
\hline 5. Turquia & 5.11 & 5. Indonésia & 3.94 \\
\hline 6. Colômbia & 5.02 & 6. Tanzânia & 2.63 \\
\hline 7. Filipinas & 4.90 & 7. Sudão & 2.42 \\
\hline 8. Iugoslávia & 4.65 & 8. Quênia & 1.90 \\
\hline 9. Tailândia & 3.60 & 9. Burma & 1.73 \\
\hline 10. Romênia & 3.24 & 10. Etiópia & 1.72 \\
\hline Total & $\mathbf{5 6 . 3 9}$ & Total & $\mathbf{7 2 . 0 2}$ \\
\hline
\end{tabular}

Fonte: Banco Mundial. Annual Report. 1981, p. 156-157 e 174-75.

\footnotetext{
${ }^{115}$ PAYER, Cheryl. Lent and lost: foreign credit and Third World development. $1^{\mathrm{a}}$ edição. Londres/ Nova Jersey: Zed Books, 1991, p. 64-67.

${ }^{116}$ McNAMARA, Robert. Discurso anual ante la Junta de Gobernadores. Washington: 30 de setembro, 1980, p. 33.
} 


\section{Conclusões}

Durante a gestão McNamara, o Banco Mundial cresceu e diversificou suas operações financeiras e não-financeiras numa escala inédita até então. Esse movimento expansivo escorou-se no apoio do governo Nixon, interessado em fortalecer a assistência multilateral ao desenvolvimento frente à bilateral, mais onerosa economicamente e mais vulnerável às críticas domésticas à política externa que se avolumavam em torno da derrocada dos EUA na guerra do Vietnã.

A conexão entre desenvolvimento e segurança - dos EUA e do "mundo livre" - deu o tom da gestão McNamara, a partir da qual emergiu a consigna do "assalto à pobreza" como expediente político. $\mathrm{O}$ instrumento principal dessa abordagem foi o "desenvolvimento rural integrado", impulsionado para difundir as relações capitalistas no campo e os pacotes tecnológicos da revolução verde entre parcelas do campesinato, considerado pelo establishment norte-americano como o grupo social decisivo naquele período para a manutenção da ordem política.

Com fartos recursos em caixa, uma política de empréstimos agressiva e a estruturação da área de pesquisa durante o primeiro quinquênio da gestão McNamara, o Banco consolidou, durante os anos setenta, o papel de liderança no âmbito da assistência internacional ao desenvolvimento. A pesquisa foi decisiva para dar suporte e legitimidade à "cruzada contra a pobreza". Com o lançamento dos programas de ajustamento estrutural em 1980, a ideia de "combate à pobreza" ganhou um novo e poderoso veículo de difusão, rapidamente impondo uma maneira específica de pensar e fazer política social nos meios rural e urbano, baseada na separação teórica entre produção da pobreza e produção da riqueza, no rebaixamento das provisões públicas a mínimos sociais e na imposição de cobranças aos "consumidores" (recuperação de custos).

Com McNamara, a capacidade do Banco de combinar empréstimos, pensamento econômico e prescrições políticas alcançou níveis nunca alcançados até então. Historicamente, a carteira de empréstimos do Banco funcionou como instrumento para fazer circular, internalizar e institucionalizar o produto principal: ideias econômicas e prescrições políticas sobre o que fazer, como e para quem em matéria de desenvolvimento capitalista, nas suas mais variadas dimensões. Dialogando com as pesquisas que, de diferentes ângulos e abordagens, enfatizam não apenas a dimensão econômica da atuação dessa entidade, mas também o seu papel político e intelectual, ${ }^{117}$ este artigo pretendeu mostrar, ainda que sinteticamente, como essa estranha espécie de banco consolidou-se como a principal

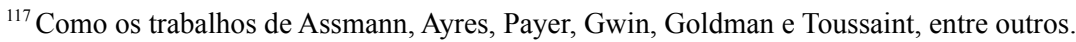


agência internacional de desenvolvimento durante a gestão McNamara, a que pressões respondeu e a que interesses serviu. A argumentação apresentada insistiu na tese ${ }^{118}$ de que a trajetória política do Banco foi determinada pela sua condição singular de emprestador, promotor de políticas e difusor de ideias produzidas pelo mainstream anglo-saxônico e disseminadas por ele ou produzidas por ele em sintonia com o mainstream. A construção político-intelectual do "combate à pobreza" fez parte dessa trajetória, assim como a imposição do "ajustamento estrutural" no centro do debate econômico e da agenda política internacional.

Recebido: 08/09/2010 - Aprovado: 18/05/2011.

${ }^{118}$ Discutida extensamente em PEREIRA, João Márcio Mendes. O Banco Mundial como ator político, intelectual e financeiro (1944-2008). Rio de Janeiro: Civilização Brasileira, 2010. 